\title{
Yerel Halkın Türkiye'de Bulunan Suriyelilere Yönelik Tutumunun Araştırılması: Kahramanmaraş Örneği
}

\section{Research of Local People's Attitudes toward the Syrians in Turkey: A Case Study of Kahramanmaraş}

\section{Bekir Güzel' 1 (1)}

Öz

Türkiye'ye yönelik gerçekleşen uluslararası göç hareketleri 2000'li yıllardan itibaren giderek artmaktadır. Özellikle 2011 yılından itibaren Suriye sınırında gerçekleşen kitlesel sığınma talepleri neticesinde, bugün yaklaşık dört milyon Suriyeli Türkiye'de yaşamaktadır. Tarama deseni kullanılarak Kahramanmaraş'ta gerçekleştirilen bu araştırmada yerel halkın Suriyelilere yönelik tutumu incelenmiştir. Araştırmada Özüdoğru, Kan, Uslu ve Yaman (2018) tarafindan geliştirilen Yerel Halkın Suriyelilere Yönelik Tutum Ölçeği (YHSYTÖ) kullanılmıştır. Bu araştırmada veriler kolayda örnekleme yöntemine uygun olarak toplanmış ve 405 katılımcı ile görüşülmüştür. Veriler 20 Ağustos-30 Kasım 2020 tarihleri arasında Kahramanmaraş il merkezinde ikamet eden ve araştrrmaya katılmaya gönüllü olan yerel halktan toplanmıştır. Araştırmanın sonuçlarına göre yerel halkın Suriyelilere yönelik tutum puanının cinsiyetine, medeni durumuna, yaş gruplarına, herhangi bir işte çalışma durumuna, ailesindeki kişi sayısına ve memleketine göre anlamlı bir fark göstermediği $(p>0,05)$; buna karşın yerel halkın Suriyelilere yönelik tutum puanında öğrenim düzeyine, mesleğine ve aylık gelir durumuna göre anlamlı bir fark bulunduğu $(p<0,05)$ tespit edilmiştir. Araştırma sonucunda yerel halkın Suriyelilere yönelik tutum puanının düşük düzeyde olduğu anlaşılmaktadır. Birlikte yaşam ve toplumsal uyum gibi konular söz konusu olduğunda hem yerel halkın hem de göç ile gelen nüfusun bakış açılarının olumlu olması oldukça önemlidir. Bunun için her iki tarafin algısını (duygu ve düşünce) ve tutumunu (davranış) olumlu yönde geliştirecek çalışmalara intiyaç duyulmaktadır. Bu noktada "Uyum Mahalle Buluşmaları" gibi çeşitli sosyal, kültürel veya dini etkinlikler (kermesler, şenlikler, kutlamalar, bayramlaşma veya kandil etkinlikleri gibi) yaygınlaştırılabilir.

\section{Anahtar Kelimeler}

Türkiye, Kahramanmaraş, Suriyeliler, Yerel halk, Tutum

1 Sorumlu Yazar: Bekir Güzel (Dr. Öğr. Üyesi), Recep Tayyip Erdoğan Üniversitesi, Sağlık Bilimleri Fakültesi, Sosyal Hizmet Bölümü, Rize, Türkiye. E-posta: bekir.guzel@erdogan.edu.tr; bekirguzell@gmail.com ORCID: 0000-0002-0795-0768

Atıf: Guzel, B. (2021). Yerel Halkın Türkiye'de Bulunan Suriyelilere Yönelik Tutumunun Araştrılması: Kahramanmaraş Örneği. Journal of Social Policy Conferences, 81, 151-183. https://doi.org/10.26650/jspc.2021.81.899619 


\begin{abstract}
Since the 2000s, international migration toward Turkey has been increasing. Particularly, because of the mass asylum requests on the Syrian border since 2011; in the present day, nearly four million Syrians live in Turkey. Here, a survey design was used to examine the attitudes of local people in Kahramanmaraş toward the Syrians. The "attitude scale of local people toward Syrians" developed by Özüdoğru, Kan, Uslu, and Yaman (2018) was used. Data collection was conducted using the convenience sampling method, and 405 participants were interviewed between 20 August and 30 November 2020. The data were collected from local people who volunteered to participate in the research and resided in Kahramanmaraş. As per the study results, it was determined that the local people's attitude score toward Syrians did not show a significant difference ( $p>0.05$ ) according to their gender, marital status, age groups, employment status, the number of members in their family, and hometown. However, a significant difference $(p<0.05)$ in the attitude score of local people toward Syrians according to their education level, profession, and monthly income was revealed. Thus, the attitude score of the local people toward Syrians is at a low level. When it comes to issues, such as living together and social cohesion, the perspectives of both the local people and the migrant population must be positive. Therefore, studies that will positively improve both parties' perception (emotion and thought) and attitude (behavior) are needed. At this point, various social, cultural, or religious activities, such as "cohesion neighborhood meetings" (kermesses/bazaars, festivals, celebrations, feasts, kandils, or blessed nights) can be expanded.
\end{abstract}

\title{
Keywords
}

Turkey, Kahramanmaraş, Syrians, Local people, Attitude 


\section{Extended Summary}

Since the 2000s, international migration toward Turkey has been increasing. Official data and academic research on the subject (İçduygu and Aksel, 2012; GIGM, 2020), also justify this claim. Particularly, due to the mass asylum requests on the Syrian border since 2011; in the present day, nearly four million Syrians have been living in Turkey. However, a big consideration is that these migrations are massive and concentrated in certain regions rather than the quantitative excess of data. Actually, most Syrians under temporary protection status in Turkey live densely in İstanbul, Gaziantep, Hatay, Adana, Kilis, and other cities close to the Syrian border (GİGM, 2020).

Within the scope of this study conducted in the Kahramanmaraş Province, answers to the following questions were sought: (1) What is the attitude of local people in Kahramanmaraş toward Syrians? (2) Is there a relationship between the sociodemographic characteristics of local people in Kahramanmaraş and their attitude toward Syrians?

In this study, survey design - one of the quantitative research methods - was used. The data obtained through this study are based on the principle of predicting the universe, making generalizations, or forming an opinion about the universe (Demirel, 2018). The survey design was preferred in this study because it provides the opportunity to determine the participants' opinions on any subject or to determine their characteristics, such as interest, perception, attitude, and behavior (Demirel, 2018). The research universe consists of the local people in Kahramanmaraş. In this study, data were collected following the convenience sampling method, and 405 participants were interviewed. In this method, the choice for selecting the sample unit belongs to the researcher. The researcher requests the person whom he/she considers appropriate to participate in the research. If the participant agrees, the data collection process commences. This method makes it possible to collect data from the main mass (universe) easily, quickly, and economically. (Haşıloğlu, Baran and Aydın, 2015). In the research, the "Attitude Scale of Local People toward Syrians," developed by Hülya Yiğit Özüdoğru, Adnan Kan, Latife Uslu, and Esra Yaman in 2018, was used. The data were collected between 20 August and November 30,2020 , from local people who volunteered to participate in the study and resided in Kahramanmaraş. Data collection was conducted by physically interviewing each participant or via phone call and processed in an Excel sheet; 
collated data were analyzed using the SPSS v.21.0 program. The Skewness and Kurtosis coefficients were used in testing the normality of the scale scores. Since the scores did not show a normal distribution and the number of samples in the groups was different, the Mann-Whitney U-test was used to compare the variables of gender, marital status, employment status, and hometown. Additionally, the Kruskal-Wallis H-test was used to compare the variables of age, education level, occupation, monthly income, and the number of people in the family. When a significant difference was observed in the Kruskal-Wallis H-test, the Mann-Whitney U- test was used to determine the difference between groups. The Pearson correlation test was used to analyze the relationship between the subscale scores of the scale.

In this research, the attitude score of the local people toward Syrians $(2.36 \pm 0.90)$ was in the "disagree" range and low level. When the subscale scores were examined, the acceptance score $(1.80 \pm 0.88)$ was in the range of "strongly disagree/disagree" and at a low level; seen as a threat, (3.60 \pm 1.15$)$ subscale score was in the "agree" range and at a high level; rejection $(3.12 \pm 1.24)$ subscale score was found to be in the range of "neutral" and at a moderate level. As per the results of this study, it was determined that the local people's attitude score toward Syrians $(2.36 \pm 0.90)$ did not show a significant difference ( $>0.05$ ) according to their gender, marital status, age groups, employment status, the number of members in their family, and hometown. However, it was revealed that there was a significant difference $(p<0.05)$ in the attitude score of locals toward Syrians according to their education level, profession, and monthly income. Moreover, a negative and significant relationship was found between the scores of the acceptance subscale toward Syrians and the scores of seeing them as a threat $(\mathrm{r}=-0.43 ; \mathrm{p}<0.05)$ and rejecting them $(\mathrm{r}=-0.49$; $\mathrm{p}<0.05$ ). A positive and significant relationship was found between the scores of the subscale seen as a threat to Syrians and the rejection scores $(r=0.69$; $\mathrm{p}<0.05)$.

The results indicated the following: (1) Participants with high acceptance scores for Syrians also had low scores of seeing Syrians as a threat and rejecting them. (2) Participants with high scores of seen as a threat to the Syrians also have high rejection scores. When these research results and other studies in the literature were evaluated as a whole, it was understood that negative (low level) perceptions and attitudes toward Syrians have continued since 2014. 
Today, it is known that social/mutual harmony and coexistence studies are necessary for the locals to develop a positive perception and attitude toward newcomers. As an output of this study, it is recommended that the aforementioned studies be conducted at the regional and local levels. Therefore, different stakeholders, such as governorship, local administrations, provincial directorates of migration management, provincial directorates of culture and tourism, mufti offices, local press and media organizations, and mukhtar and nongovernmental organizations have important responsibilities. 


\section{Yerel Halkın Türkiye'de Bulunan Suriyelilere Yönelik Tutumunun Araştırılması: Kahramanmaraş Örneği}

"Şu anda sakin olduğumu söyleyemem; ama sessizim. Kalp atışlarımın uzaklardan gelen bir patlama sesini andıran çarpıntısını duyabiliyorum; silah seslerinden, çocuk çı̆̆lıklarından ve annelerin feryatlarından daha net. Annemin sokağa çıkmamam için bana yalvarırken titreyen sesinden daha net: Her yerde katiller var, her yerde ölüm. Köyde, şehirde, sahilde... Hepimizi öldürecekler!’

Suriyeli gazeteci ve yazar Samar Yazbek (2012, s. 1) ülkesinde çıkan iç çatışmanın ilk dört ayını kaleme aldığı günlüklerine yukarıdaki sözlerle başlıyor. Yazbek' in bu satırları kaleme almasından yaklaşık bir ay sonra Suriye Arap Cumhuriyeti ${ }^{1}$ vatandaşı olan 252 kişilik bir grup Hatay'da bulunan Yayladağ Sınır Kapısı'na gelerek Türkiye'ye sığınma talebinde bulunmuştur. Sonraki süreçte başta Hatay olmak üzere Türkiye'nin güneyinde bulunan Gaziantep, Adana, Şanlıurfa, Mardin, Osmaniye ve Kahramanmaraş gibi illerde geçici barınma merkezleri (kamplar) açılmıştır. 2020 yılının Aralık ayı itibariyle de 3 milyon 641 bin 370 Suriye vatandaşı Türkiye'de geçici koruma statüsü kapsamında ikamet etmektedir (GİGM, 2020). Kitlesel olarak gerçekleşen göç hareketlerinin hem göç veren hem de göç alan bölgelerde/ülkelerde önemli sosyodemografik değişimlere yol açtığı bilinmektedir (Champion, 1994; Castles ve Miller, 2008; Çaro ve Van Wissen, 2008). Hatta bu değişimler o kadar etkilidir ki; bir ülkenin inşasına ya da yok olmasına yol açabilir (İçduygu, Sirkeci, ve Aydıngün, 1998). Göç veren ülkeler maddi (üretime dayalı gelir ve vergi kaybı gibi) ve manevi açılardan (yetişmiş insan gücü, geleceğe yönelik umut ve inanç kaybı gibi) çeşitli zorluklarla yüzleşmek durumunda kalırken; göç alan ülkeler de sosyal, kültürel, ekonomik ve politik açılardan önemli farklılıklar yaşamaktadır. Göç hareketlerini ve bu hareketlere bağlı olarak ülkelerde yaşanan değişimleri açıklamak için 19. yüzyılın sonlarından itibaren çeşitli kuramsal çalışmaların yapıldığı bilinmektedir. Bu kuramsal çalışmalarda öncelikle göç hareketlerine odaklanıldığı (Ravenstein, 1885); sonraki süreçte göç eden bireylerin de değerlendirmelere dâhil edildiği (Lee, 1966) görülmektedir. Göç kuramları sonraki yıllarda ekonomik temelli açıklamalardan (Stouffer, 1940; Piore, 1979; Stark, 1991) sosyal, kültürel ve psikolojik boyuttaki açıklamalara (Abadan-Unat, 2006; Castles ve Miller, 2008; Faist, 2012) evrilmiştir.

1 Çalışmanın devamında Suriye Arap Cumhuriyeti ifadesi kısaltılarak Suriye olarak kullanılacaktır. 
Göç hareketlerinin giderek arttığı 21. yüzyılda sosyal, kültürel ve psikolojik boyuttaki çalışmaların daha çok entegrasyon, toplumsal/karşılıklı uyum ve birlikte yaşam gibi konular üzerinde yoğunlaştı̆̆ 1 görülmektedir. Söz konusu kavramlar ve konular hakkında çeşitli tartışmalar (Brüß, 2003; Penninx ve Garcés-Mascareñas, 2016) olmakla birlikte; bu çalışmalarda esas olarak göç eden bireylerin yeni geldikleri toplum ile olan iletişimi ve ilişkisi ele alınmaktadır. Özellikle Batı Avrupa merkezli çalışmalarda bu konunun daha çok göç eden bireylerden hareketle ele alındığı; bu bireylerin yeni geldikleri topluma olan entegrasyonu üzerine odaklanıldığı anlaşılmaktadır (Jacob, 1194; Valtonen, 1999; Favell, 2001). Fakat zamanla bu bakış açısının eleştirildiği (Gray, 2006) ve yerel toplumun da çalışmalara dâhil edildiği görülmektedir (Hickman, Mai ve Crowley, 2012; Dukes ve Musterd, 2012). Bu çalışmalarda hem yeni gelenlerin yerel toplum hakkındaki düşünceleri hem de yerel toplumun yeni gelenler hakkındaki düşünceleri ele alınmaktadır. Bu çalışmada da yerel halkın Kahramanmaraş ilinde ikamet eden geçici koruma statüsü sahibi Suriyelilere yönelik tutumu araştırılmaktadır.

\section{Literatür Taraması: Türkiye'de Bulunan Suriyelilere Yönelik Algı ve Tutum Araştırmaları}

Türkiye'ye yönelik gerçekleşen uluslararası göç hareketleri 2000'li yıllardan itibaren giderek artmaktadır. Konuyla ilgili resmi veriler ve akademik çalışmalar da (İçduygu ve Aksel, 2012; GİGM, 2020) bu tespiti doğrular niteliktedir. Özellikle 2011 yılından itibaren Suriye sınırında gerçekleşen kitlesel sı̆̆ınma talepleri neticesinde bugün farklı ülke vatandaşlığına sahip ya da vatansız olan beş milyonun üzerinde bir nüfus Türkiye sınırları içinde ikamet etmektedir (TBMM, 2019). Buna göre Türkiye nüfusunun yaklaşık \%5'i uluslararası göç hareketleri sonucunda Türkiye'ye gelen bireylerden oluşmaktadır. Burada önemli olan verilerin niceliksel fazlalığından ziyade göç hareketlerinin kitlesel olması ve belirli bölgelerde yoğunlaşmış olmasıdır. Nitekim Suriye'den gelen ve geçici koruma statüsü altında Türkiye'de bulunan nüfusun büyük bir bölümü İstanbul ile Gaziantep, Hatay, Adana ve Kilis gibi Suriye sınırına yakın olan illerde toplanmaktadır (GİGM, 2020). Bu durum söz konusu illerde ikamet eden yerel halkın Suriyelilere yönelik algısını (duygu ve düşünce) ve tutumunu (davranış) da etkilemektedir. Son yıllarda Kilis başta olmak üzere Gaziantep, Şanlıurfa, Hatay, Adana ve Mardin gibi illerde yerel halkın Suriyelilere yönelik algısının ve tutumunun araştırıldığı çok sayıda çalışma bulunmaktadır (Cengiz, 
2015; Topkaya ve Akdağ, 2016; Y1lmaz, 2017; Doğan, 2019). Kilis ilinde yapılan bir araştırmada yerel halkın Suriye'den gelen ve sı ğınma talebinde bulunan bireylere yönelik ilk yıllarda olumlu bir algıya ve tutuma sahip oldukları; nüfusun artmasıyla olumlu olan bu algının ve tutumun olumsuza doğru evrildiği tespit edilmiştir (Cengiz, 2015). Kilis’te yapılan bir başka araştırmada bazı katılımcıların Suriyelilerin Türkiye'nin kıymetini daha iyi anlamalarını sağladıkları, empati yeteneklerini geliştirdikleri, farklı kültürleri tanıma imkanı sundukları için Suriyelilere yönelik olumlu bir algıya ve tutuma sahip oldukları tespit edilmiştir (Topkaya ve Akdağ, 2016). Aynı araştırmada bazı katılımcıların da nüfus artışına bağlı olarak alt yapı hizmetlerinde yaşanan sorunlar, ev kiraları ve fiyatlarındaki artış, sağlık ve eğitim hizmetlerine erişimde yaşanan zorluklar, çevre kirliliği ve trafik yoğunluğu gibi nedenlerden dolayı Suriyelilere yönelik olumsuz bir algıya ve tutuma sahip oldukları görülmektedir (Topkaya ve Akdağ, 2016).

1380 katılımcı ile Hatay, Adana, Gaziantep, Şanlıurfa ve Kilis illerinde yapılan bir araştırmada katılımcıların \%66'sı Suriyelilere yönelik olumsuz alg1 ve tutum içindedir. Katılımcıların yaşadıkları il, cinsiyet, öğrenim düzeyi ve ekonomik gelir gibi bazı sosyodemografik değişkenlerine göre bu oran \%70'lerin de üzerine çıkmaktadır (Yılmaz, 2017). Yapılan derinlemesine görüşmelerde katılımcıların bu olumsuz algı ve tutumlarının oluşmasına neden olan farklı etkenlerin bulunduğu anlaşılmaktadır. Buna göre katılımcıların ulusal ve bireysel güvenlik riski başta olmak üzere sosyal, kültürel, ekonomik ve politik açılardan gelecek kaygısı yaşadıkları, bu kaygının da Suriyelilere yönelik olumsuz bir alg1 ve tutumun gelişmesine neden olduğu anlaşılmaktadır (Yılmaz, 2017). Mardin ilinde yapılan bir araştırmada, Suriye'de yaşanan olayların yıkıcı, zorlayıcı ve öldürücü boyutunun çoğu katılımcının Suriyelilere yönelik bir merhamet duygusu geliştirmesine neden olduğu ifade edilmektedir (Doğan, 2019). Katılımcıların sahip olduğu bu merhamet duygusu ilk bakışta olumlu bir algı olarak değerlendirilse de; derinlemesine bir analiz yapıldığında bu duygunun temelinde empatiden ziyade ötekileştirici, dışlayıcı veya ayrıştırıcı bir algının yer aldığı anlaşılmaktadır (Doğan, 2019). Mardin ili özelinde yapılan bu araştırma Suriyelilere yönelik olumsuz algı ve tutumun oluşmasında ilk olarak ekonomik nedenlerin, daha sonra da ahlaki değerlerin etkili olduğunu ortaya koymaktadır. Üstelik sınır komşusu olmalarına ve genellikle aynı etnik/ kültürel özelliklere sahip olmalarına rağmen yerel halk ile Suriyeliler arasında ciddi bir sosyal (gruplararas1) mesafenin bulunduğu görülmektedir. Yerel halkın 
Suriyelilerin kamplarda ya da şehir merkezinin dışındaki mekânlarda ikamet etmeleri gerektiğini ifade etmesi bu mesafenin bir göstergesi olarak kabul edilebilir (Doğan, 2019). Sonuçta Suriye sınırına yakın olan bölgelerde/illerde yapılan araştırmalarda yerel halkın algı ve tutumunun Suriyelilerin geçicilikten kalıcılığa dönen varlığıyla birlikte olumludan olumsuza doğru evrildiği anlaşılmaktadır. Ancak Türkiye'de yerel halkın Suriyelilere yönelik algı ve tutumu ile ilgili olarak yapılan araştırmalar sadece Suriye sınırına yakın olan bölgeler/iller ile sınırlı değildir. Başta İstanbul (Çalışkan, 2019) olmak üzere Ankara (Kemik, Gözübüyük ve Sever, 2019), İzmir (Çetin, 2017), Aydın (Saçan, Cizdan ve Tabak 2017), Trabzon (Gözübüyük Tamer, 2016), Bolu (Güney ve Konak, 2016) ve Elazığ (Budak, 2017) gibi illerde yapılan farklı çalışmalar da bulunmaktadır. Bu çalışmalarda yerel halkın Suriyelilere yönelik ekonomik nedenler, sosyokültürel faktörler, ulusal güvenlik tehdidi ve sosyal refah hizmetlerine erişim engeli gibi farklı nedenlerden dolayı olumsuz bir algı ve tutuma sahip oldukları sonucuna varılmıştır.

Literatürde, Kahramanmaraş’ta bulunan Suriyeliler ile ilgili farklı çalışmalar bulunmakta olup bu çalışmaların önemli bir bölümü Suriyelilerin eğitim, sağlık, beslenme, bakım ve barınma gibi hizmetlere erişimleriyle ilgilidir (Özkaya, Kirişci, Çalışkan, Tümer ve Şenol, 2015; Dülgergil, Demirel, Göçebe ve Dalli, 2017; Orak, 2019). Bu çalışmanın amacına uygun olarak yerel halkın Suriyelilere yönelik algı veya tutumunu inceleyen iki farklı ampirik çalışmaya rastlanılmıştır. Bu çalışmaların hiçbiri doğrudan Suriyelilere yönelik alg1 ve/veya tutuma yönelik değildir. Çalışmaların ilkinde yerel halkın Suriyelilere yönelik tutumu sosyoekonomik ve politik bağlamda ele alınmıştır (Aydın ve Durgun, 2018). Örneklem hacmi 384 kişi olan bu nicel çalışmada katılımcıların istihdam imkânlarının azalması, bazı yerlerin/mekânların sadece Suriyeliler tarafından kullanılması, konut/işyeri fiyatlarının artması, Suriyelilerin beklenmedik nüfus artışı ve bu durumun ulusal politikaya etki etmeye başlaması gibi nedenlerle Suriyelilere yönelik olumsuz bir tutuma sahip oldukları tespit edilmiştir. Bu tespitin en somut göstergesi ise katılımcıların \%64,1'inin (246 kişinin) hiçbir şekilde Suriyeliler ile ilişki kurmadığını ifade etmesidir² (Aydın ve Durgun, 2018). Kahramanmaraş'ta gerçekleştirilen diğer çalışmanın örneklemini esnaf olan katılımcılar oluşturmakta ve esnafın sosyoekonomik durumu ile Suriyelere

2 Göç çalışmalarında bu konuyla ilgili olarak değerlendirilebilecek ve uygulanabilecek çok farklı yollar olmakla birlikte bu çalışmanın mahiyeti itibariyle burada herhangi bir açıklamaya veya değerlendirmeye yer veril(e)memiştir. 
yönelik algısı incelenmektedir. Nicel bir araştırma deseni kullanılarak gerçekleştirilen bu araştırmanın örneklem hacmi 1002 kişiden oluşmaktadır. Araştırmaya katılan esnafin yaklaşı \% \%60'1 (601 kişi) Suriyelilerin gelişinden sonra işlerinin ve gelirlerinin arttığını; yaklaşık \%30'u (300 kişi) ise azaldığını ve iş değiştirmek zorunda kaldığını ifade etmiştir. Bu sonuçlara göre esnafın büyük bir bölümünün gelir kaybına uğramamış olması nedeniyle olumlu bir algıya sahip oldukları düşünülebilir. Fakat katılımcıların sadece \%27'sinin (270 kişinin) Suriyeliler ile komşu olmaktan herhangi bir rahatsızlık duymayacağını ifade etmiş olması Suriyelilere yönelik mesafeli ve temkinli olduklarını ortaya koymaktadır. (Harunoğulları, Hatunoğlu, Polat ve Kılıç, 2018).

Kahramanmaraş’ta gerçekleştirilen bu çalışma kapsamında aşağıdaki sorulara yanıt aranmıştır;

(1) Kahramanmaraş’taki yerel halkın Suriyelilere yönelik tutumu nasıldır?

(2) Kahramanmaraş'taki yerel halkın sosyodemografik özellikleri ile Suriyelilere yönelik tutumları arasında ilişki var mıdır?

\section{Araştırmanın Yöntemi}

$\mathrm{Bu}$ araştırmada nicel araştırma türleri arasında yer alan tarama deseni kullanılmıştır. Tarama deseni yoluyla örneklemden elde edilen veriler; evren hakkında bir tahminde bulunma, genelleme yapma ya da evren ile ilgili bir kanaat oluşturma esasına dayanmaktadır (Demirel, 2018). Bu bağlamda tarama deseni mevcut durumu olduğu gibi, herhangi bir öznel yoruma gerek duymadan, açıklama amacı taşımaktadır (Şimşek, 2012). Tarama deseni herhangi bir konuyla ilgili katılımcıların görüşlerinin tespit edilmesi ya da ilgi, alg1 ve tutum gibi özelliklerinin belirlenmesi imkânı sunması (Demirel, 2018) nedeniyle bu araştırmada tercih edilmiştir.

\section{Evren ve Örneklem}

Araştırma evrenini Kahramanmaraş'taki yerel halk oluşturmaktadır. Bu çalışmada Kahramanmaraş'ın araştırma sahası olarak tercih edilmesinin nedeni, bu ilde daha önce doğrudan Suriyelilere yönelik kapsamlı bir tutum araştırmasının yapılmamış olmasıdır. Nitekim Suriyelilerin illere göre dağılımında Türkiye ortalaması \%4,37 iken; Kahramanmaraş’ta bulunan 92 bin 594 Suriyelinin yerel halka oranı \%8,02'dir (GİGM, 2020). Dolayısıyla Türkiye ortalamasının 
üzerinde Suriyeli nüfusuna sahip olan bir ilde yerel halkın algısını ve tutumunu araştıran farklı çalışmalara ihtiyaç duyulmaktadır. Bu araştırmada veriler, tesadüfî olmayan örnekleme yöntemleri arasında yer alan kolayda örnekleme yöntemine uygun olarak toplanmıştır. Bu yöntemde örneklem biriminin seçimi araştırmacıya bırakılmıştır. Araştırmacı uygun olduğunu düşündüğü örnekleme araştırmaya katılım teklifinde bulunur ve kabul durumuna göre veri toplama süreci başlatılır. Bu yöntemle ana kütleden kolay, hızlı ve ekonomik şekilde veri toplanması mümkün olmaktadır (Haşıloğlu, Baran ve Aydın, 2015). Ancak bu yöntemle toplanan verilerin teorik olarak evrene genellenebilmesi mümkün olmamaktadır. Bu araştırmada toplam 405 katılımcı ile görüşülmüştür.

Tablo 1

Katılımcıların Demografik Özelliklerine Göre Dağılımı

\begin{tabular}{|c|c|c|c|}
\hline Demografik Değişken & Gruplar & n & $\%$ \\
\hline \multirow{2}{*}{ Cinsiyet } & Kadın & 150 & 37,0 \\
\hline & Erkek & 255 & 63,0 \\
\hline \multirow{6}{*}{$\begin{array}{l}\text { Yaş } \\
\text { (18-85 yaş aralığı) }\end{array}$} & 20 yaş ve altı & 61 & 15,1 \\
\hline & $21-30$ yaş & 128 & 31,6 \\
\hline & $31-40$ yaş & 119 & 29,4 \\
\hline & $41-50$ yaş & 70 & 17,3 \\
\hline & $51-60$ yaş & 13 & 3,2 \\
\hline & 61 yaş ve üstü & 14 & 3,5 \\
\hline \multirow{2}{*}{ Medeni durum } & Evli & 252 & 62,2 \\
\hline & Bekâr & 153 & 37,8 \\
\hline \multirow{4}{*}{ Öğrenim düzeyi } & İlkokul & 97 & 24,0 \\
\hline & Ortaokul & 73 & 18,0 \\
\hline & Lise & 131 & 32,3 \\
\hline & Üniversite & 104 & 25,7 \\
\hline \multirow{6}{*}{ Meslek } & Kamu çalışanı & 26 & 6,4 \\
\hline & Özel sektör çalışanı & 157 & 38,8 \\
\hline & Serbest meslek & 57 & 14,1 \\
\hline & Ev hanımı & 71 & 17,5 \\
\hline & Öğrenci & 47 & 11,6 \\
\hline & Mesleği yok/emekli & 47 & 11,6 \\
\hline \multirow{2}{*}{$\begin{array}{l}\text { Gelir getirici bir işte çalışma } \\
\text { durumu }\end{array}$} & Çalışmiyor & 171 & 42,2 \\
\hline & Çalışıyor & 234 & 57,8 \\
\hline
\end{tabular}




\begin{tabular}{|l|l|c|c|}
\hline \multirow{5}{*}{ Aylık gelir } & $1000 \mathrm{TL}$ ve alt & 133 & 32,8 \\
\cline { 2 - 4 } & $1001-2000 \mathrm{TL}$ & 52 & 12,8 \\
\cline { 2 - 4 } & $2001-3000 \mathrm{TL}$ & 159 & 39,3 \\
\cline { 2 - 4 } & $3001-4000 \mathrm{TL}$ & 37 & 9,1 \\
\cline { 2 - 4 } & $4001 \mathrm{TL}$ ve üstü & 24 & 5,9 \\
\hline \multirow{5}{*}{ Ailedeki kişi sayıs1 } & 2 kişi & 28 & 6,9 \\
\cline { 2 - 4 } & 3 kişi & 72 & 17,8 \\
\cline { 2 - 4 } & 4 kişi & 112 & 27,7 \\
\cline { 2 - 4 } & 5 kişi & 83 & 27,2 \\
\cline { 2 - 4 } & 6 kişi ve üstü & 32 & 92,5 \\
\hline \multirow{3}{*}{ Memleketi } & Kahramanmaraş & 7,9 \\
\cline { 2 - 4 } & Diğer & & 92,1 \\
\hline
\end{tabular}

\section{Veri Toplama Araçları}

Araştırmada iki farklı veri toplama aracı kullanılmıştır. Bunlardan ilki araştırmacı tarafından geliştirilen Sosyodemografik Bilgi Formu'dur. Bu form katılımcıların Suriyelilere yönelik tutumu ile sosyodemografik özellikleri (cinsiyet, medeni durum, yaş, öğrenim düzeyi, meslek, gelir getirici bir işte çalışma durumu, aylık gelir, ailedeki kişi sayısı, memleket) arasında herhangi bir ilişki olup olmadığının tespit edilebilmesi amacıyla hazırlanmıştır.

Araştırmada kullanılan diğer form 2018 yılında Hülya Yiğit Özüdoğru, Adnan Kan, Latife Uslu ve Esra Yaman tarafından geliştirilen Yerel Halkın Suriyelilere Yönelik Tutum Ölçeği (YHSYTÖ)'dir. 5'li likert tipinden (1: kesinlikle katılmıyorum, 5: kesinlikle katılıyorum) oluşan ölçek kendi içinde kabul etme (1-11), tehdit (12-21) ve reddetme (22-26) olmak üzere üç alt bölümden oluşmaktadır. Ölçeğin toplam puanı alınırken tehdit olarak görme ve reddetme puanları ters kodlanmaktadır. Ölçekte ortaya çıkan yüksek puan ile yerel halkın Suriyelilere yönelik tutumunun yüksek düzeyde olumlu olduğu anlaşılmaktadır. Bu çalışmada ölçeğin Cronbach Alpha katsayısı 0,95; alt boyutların Cronbach Alpha katsayıları sırasıyla 0,95 / 0,94 / 0,91 olarak tespit edilmiştir.

\section{Veri Toplama Süreci}

Veriler 20 Ağustos-30 Kasım 2020 tarihleri arasında Kahramanmaraş il merkezinde ikamet eden ve araştırmaya katılmaya gönüllü olan yerel halktan toplanmıştır. Veriler her bir katılımcı ile yüz yüze ya da telefonda görüşülerek 
toplanmış; Excel dosyasına işlenmiştir. Bu süreçte Kahramanmaraş il merkezinde ikamet eden, daha önce bilimsel araştırma yöntemleri dersi almış olan bir üniversite son sınıf öğrencisinden ücretli destek hizmeti alınmıştır. Saha araştırması öncesinde araştırmacı tarafından öğrenciye bilimsel araştırma yöntemleri, araştırma ölçeği ve veri toplama süreçleri gibi temel konular hakkında kısa bir eğitim verilmiştir. Bu eğitimde gerçekleştirilmesi planlanan araştırma hakkında detaylı bilgiler paylaşılmıştır.

\section{Araştırmanın Sınırlılıkları}

Bu araştırmanın (1) veri toplama sürecinin Covid-19 salgını sonrasında ilan edilen pandemi sürecine denk gelmesi; (2) kullanılan ölçekte Suriyelilere yönelik bazı dışlayıcı ve damgalayıcı ifadelerin (özellikle tehdit ve reddetme alt boyutlarında) yer alması; (3) yerel halkın arasında kadınların toplumsal yaşama katılım oranının düşük olması gibi üç temel başlık altında toplanabilecek sınırlı1ıkları bulunmaktadır. Bu sınırlılıklar katılımcıların gönüllülük esasına uygun olarak ikna edilmesinde, veri toplama sürecinin planlanan süreler içinde tamamlanamamasında ve katılımcıların cinsiyet dağılımının dengeli olmamasında ${ }^{3}$ etkili olmuştur.

\section{Verilerin Analiz Edilmesi}

Veriler, SPSS 21.0 programı kullanılarak analiz edilmiştir. Ölçek puanlarının normallik sınamasında çarpıklık ve basıklık katsayıları kullanılmıştır. Sürekli bir değişkenden elde edilen puanların normal dağılım özelliğinde kullanılan çarpıklık ve basıklık katsayılarının \pm 1 sınırları içinde kalması puanların normal dağılımdan önemli bir sapma göstermediği şeklinde yorumlanabilir (Büyüköztürk, 2019). Normal dağılım göstermeyen puanlar ile non-parametrik testler yapılabileceği gibi uygun dönüşümlerle normal dağılımı sağlanarak parametrik testler de yapılabilir (Büyüköztürk, 2019). Puanların normal dağılım göstermediği ve gruplardaki örneklem sayısı farklı olduğundan cinsiyet, medeni durum, gelir getirici bir işte çalışma durumu, yaşamın çoğunu geçirdiği yer değişkenlerine göre karşılaştırılmasında Mann-Whitney U testinden; yaş, öğrenim düzeyi, meslek, aylık gelir, ailedeki kişi sayısı değişkenlerine göre karşılaştırılmasında Kruskal-Wallis H testinden yararlanılmıştır. Kruskal-Wallis

3 Kahramanmaraş örnekleminde yapılan bir başka çalışmada da kadınların araştırmaya katılım oranı benzerlik göstermektedir. Detaylı bilgi için bkz. Aydın, A. H. \& Durgun, S. (2018). Kahramanmaraş’taki Suriyeli sığınmacıların yerel halk tarafından sosyo-ekonomik ve politik açıdan değerlendirilmesi. Kahramanmaraş Sütçü İmam Üniversitesi Sosyal Bilimler Dergisi, 15(2), s. 501-526. 
H testinde anlamlı farklılık görüldüğünde farkın hangi gruplar arasında olduğunu belirlemek amacıyla Mann-Whitney U ikili karşılaştırma testinden yararlanılmıştır. Ölçeğin alt boyut puanları arasındaki ilişkinin analizinde Pearson korelasyon testinden yararlanılmıştır. Analizlerde güven aralığı \%95 $(\mathrm{p}<0,05)$ olarak belirlenmiştir.

\section{Bulgular}

Araştırmaya katılan 405 kişinin \%37'si kadın, \%63'ü erkektir. Katılımcılar 18 ile 85 yaş aralığındadır. Yaş ortalaması 32,9 olarak hesaplanmıştır. Katılımcıların \%15,1'i 20 yaş ve altı, \%31,6'sı 21-30 yaş arası, \%29,4'ü 31-40 yaş aras1, \%17,3'ü 41-50 yaş arası, \%3,2'si 51-60 yaş arası, \%3,5'i 61 yaş ve üstüdür. Katılımcıların \%62,2'si evli, \%37,8'i bekârdır. Katılımcıların \%24'ü ilkokul, \%18'i ortaokul, \%32,3'ü lise, \%25,7'si üniversite düzeyinde öğrenim görmüştür. Katılımcıların \%6,4'ü kamu çalışanı, \%38,8'i özel sektör çalışanı, \%14,1'i serbest meslek sahibi, \%17,5'i ev hanımı, \%11,6's1 öğrenci, \%11,6's1 mesleği yok/emeklidir. Katılımcıların \%57,8'i gelir getirici herhangi bir işte çalışmaktadır. Katılımcıların \%32,8'inin aylık geliri 1000TL ve altı, \%12,8'inin 1001-2000TL aras1, \%39,3'ünün 2001-3000TL aras1, \%9,1'inin 3001-4000TL arası, \%5,9'unun aylık geliri ise 4001TL ve üstüdür. Katılımcıların \%6,9'unun ailesinde iki kişi yaşamakta, \%17,8'inin ailesinde üç kişi, \%27,7'sinin ailesinde dört kişi \%27,2'sinin ailesinde beş kişi, \%20,5'inin ailesinde ise altı ve daha fazla kişi yaşamaktadır. Katılımcıların \%92,1'i Kahramanmaraş’ta doğup büyümüş, \% 7,9'u başka şehirden Kahramanmaraş’a göç etmiştir.

Tablo 2

Ölçek Ve Alt Boyut Puanlarına Ait Betimsel İstatistikler

\begin{tabular}{|l|c|c|c|c|}
\hline & & SS & $\mathbf{C ̧}$ & $\mathbf{B}$ \\
\hline Kabul Etme & $\mathbf{1 , 8 0}$ & $\mathbf{0 , 8 8}$ & $\mathbf{1 , 1 5}$ & $\mathbf{0 , 7 4}$ \\
\hline 1. Suriyeli bir arkadaşım olmasını isterim. & 1,89 & 1,18 & 1,09 & 0,05 \\
\hline 2. Suriyelilerin uyumlu insanlar olduğuna inanırım. & 1,88 & 1,06 & 1,05 & 0,31 \\
\hline 3. Suriyelilere güvenirim. & 1,69 & 0,99 & 1,45 & 1,50 \\
\hline 4. Suriyelileri severim. & 1,88 & 1,13 & 1,13 & 0,35 \\
\hline 5. Suriyelileri yakından tanımak isterim. & 1,88 & 1,17 & 1,15 & 0,23 \\
\hline 6. Suriyelileri kendime yakın bulurum. & 1,71 & 1,05 & 1,58 & 1,80 \\
\hline 7. Suriyelilerin toplumumuza çeşitlilik kattığına inanırım. & 1,90 & 1,19 & 1,16 & 0,25 \\
\hline 8. Suriyeliler ile zaman geçirmekten hoşlanırım. & 1,66 & 0,95 & 1,51 & 1,77 \\
\hline 9. Suriyeli biriyle tanışmaktan mutluluk duyarım. & 1,87 & 1,12 & 1,15 & 0,39 \\
\hline 10. Suriyelilere sempati duyarım. & 1,74 & 1,04 & 1,44 & 1,35 \\
\hline 11. Suriyelileri fursat buldukça ziyaret ederim. & 1,72 & 1,08 & 1,72 & 2,34 \\
\hline Tehdit Olarak Görme & $\mathbf{3 , 6 0}$ & $\mathbf{1 , 1 5}$ & $\mathbf{- 0 , 6 0}$ & $\mathbf{- 0 , 5 8}$ \\
\hline
\end{tabular}




\begin{tabular}{|l|c|c|c|c|}
\hline 12. Suriyelileri tehdit olarak algılarım. & 3,19 & 1,47 & $-0,12$ & $-1,37$ \\
\hline 13. Suriyelilerin ülke güvenliğini tehdit ettiğini düşünürüm. & 3,45 & 1,45 & $-0,46$ & $-1,14$ \\
\hline 14. Suriyelilerin Türkiye'de yaşamalarını istemem. & 3,71 & 1,43 & $-0,78$ & $-0,81$ \\
\hline 15. Suriyelilerin ülke ekonomisine zarar verdiğini düşünürüm. & 3,74 & 1,44 & $-0,86$ & $-0,68$ \\
\hline 16. Suriyelilerin suç oranlarını artırdığını düşünürüm. & 3,60 & 1,38 & $-0,65$ & $-0,84$ \\
\hline 17. Suriyelilerin yoksulluğu artırdığını düşünürüm. & 3,74 & 1,37 & $-0,82$ & $-0,61$ \\
\hline 18. Suriyelilerin Türkiye'yi yaşanmaz hale getirdiğini inanırım. & 3,59 & 1,40 & $-0,60$ & $-0,96$ \\
\hline 19. Suriyelilerin Türkiye'ye yük olduğuna inanırım. & 3,73 & 1,37 & $-0,81$ & $-0,63$ \\
\hline 20. Suriyelilerin varlığından tedirgin olurum. & 3,52 & 1,42 & $-0,53$ & $-1,06$ \\
\hline 21. Suriyelilerin toplumsal sorunlara yol açtığını düşünürüm. & 3,74 & 1,35 & $-0,84$ & $-0,53$ \\
\hline Reddetme & $\mathbf{3 , 1 2}$ & $\mathbf{1 , 2 4}$ & $\mathbf{0 , 0 0}$ & $\mathbf{- 1 , 0 8}$ \\
\hline 22. Suriyelileri dışlarım. & 3,05 & 1,44 & 0,05 & $-1,32$ \\
\hline 23. Suriyelilerden nefret ederim. & 3,11 & 1,46 & $-0,04$ & $-1,36$ \\
\hline 24. Suriyeliler ile karşılaştı̆̆ımda öfkelenirim. & 3,11 & 1,42 & $-0,07$ & $-1,29$ \\
\hline 25. Suriyeliler ile aynı ortamda bulunmam. & 3,44 & 1,44 & $-0,44$ & $-1,17$ \\
\hline 26. Suriyelilere selam vermem. & 2,88 & 1,50 & 0,17 & $-1,41$ \\
\hline Ölçek Toplam & $\mathbf{2 , 3 6}$ & $\mathbf{0 , 9 0}$ & $\mathbf{0 , 2 4}$ & $\mathbf{- 0 , 6 4}$ \\
\hline
\end{tabular}

Ç: Çarpıklık (Skewness); B: Basıklık (Kurtosis)

Tablo 2'de yer alan sonuçlara göre yerel halkın Suriyelilere yönelik tutum puanı $(2,36 \pm 0,90)$ "katılmıyorum" aralığında ve düşük düzeydedir. Ölçek toplam puanının düşük olması katılımcıların olumsuz tutum düzeyine; yüksek olması da olumlu tutum düzeyine sahip olduklarına işaret etmektedir. Alt boyut puanları incelendiğinde kabul etme puanı $(1,80 \pm 0,88)$ "kesinlikle katılmıyorum/ katılmıyorum" aralığında ve düşük düzeyde; tehdit olarak görme $(3,60 \pm 1,15)$ alt boyut puanı "katılıyorum" aralığında ve yüksek düzeyde; reddetme $(3,12 \pm 1,24)$ alt boyut puanı "kararsızım" aralığında ve orta düzeydedir.

Kahramanmaraş'ta yapılan bu araştırmanın sonuçlarına göre yerel halkın Suriyelilere yönelik tutum puanının $(2,36 \pm 0,90)$ katılımcıların cinsiyetine, medeni durumuna, yaş gruplarına, herhangi bir işte çalışma durumuna, ailesindeki kişi sayısına ve memleketine göre anlamlı bir fark göstermediği $(\mathrm{p}>0,05)$ tespit edilmiştir. Buna karşın yerel halkın Suriyelilere yönelik kabul etme $\left(X^{2}=18,28 ; p<0,05\right)$, tehdit olarak görme $\left(X^{2}=11,37 ; p<0,05\right)$ alt boyut puanları ve Suriyelilere yönelik tutum ölçek puanlarının $\left(X^{2}=11,04 ; p<0,05\right)$ katılımcıların öğrenim düzeyine göre anlamlı farklılık gösterdiği tespit edilmiştir. 
Tablo 3

Yerel Halkın Suriyelilere Yönelik Tutum Puanlarının Öğrenim Düzeyine Göre Karşılaştırılması

\begin{tabular}{|c|c|c|c|c|c|c|c|}
\hline Ölçek & Öğrenim & $\mathbf{n}$ & $\overline{\mathrm{X}}$ & SS & $\mathbf{X}^{2}$ & $\mathbf{p}$ & Anlamlı Fark \\
\hline \multirow{4}{*}{ Kabul Etme } & A-İlkokul & 97 & 1,64 & 0,88 & \multirow{4}{*}{18,28} & \multirow{4}{*}{0,000} & $\mathbf{D}>\mathbf{A}, \mathbf{B}, \mathbf{C}$ \\
\hline & B-Ortaokul & 73 & 1,65 & 0,65 & & & \\
\hline & C-Lise & 131 & 1,75 & 0,85 & & & \\
\hline & D-Üniversite & 104 & 2,13 & 0,99 & & & \\
\hline \multirow{4}{*}{$\begin{array}{l}\text { Tehdit Olarak } \\
\text { Görme }\end{array}$} & A-İlkokul & 97 & 3,77 & 1,17 & \multirow{4}{*}{11,37} & \multirow{4}{*}{0,010} & $\mathrm{~A}, \mathrm{C}>\mathrm{B}$ \\
\hline & B-Ortaokul & 73 & 3,32 & 1,26 & & & \\
\hline & C-Lise & 131 & 3,73 & 1,15 & & & \\
\hline & D-Üniversite & 104 & 3,47 & 1,02 & & & \\
\hline \multirow{4}{*}{ Reddetme } & A-İlkokul & 97 & 3,35 & 1,19 & \multirow{4}{*}{5,49} & \multirow{4}{*}{0,140} & \\
\hline & B-Ortaokul & 73 & 3,05 & 1,15 & & & \\
\hline & C-Lise & 131 & 3,12 & 1,33 & & & \\
\hline & D-Üniversite & 104 & 2,95 & 1,23 & & & \\
\hline \multirow{4}{*}{ TOPLAM } & A-İlkokul & 97 & 2,17 & 0,84 & \multirow{4}{*}{11,04} & \multirow{4}{*}{0,012} & $\mathrm{D}>\mathrm{A}, \mathrm{B}$ \\
\hline & B-Ortaokul & 73 & 2,42 & 0,79 & & & \\
\hline & C-Lise & 131 & 2,30 & 0,95 & & & \\
\hline & D-Üniversite & 104 & 2,57 & 0,91 & & & \\
\hline
\end{tabular}

$\mathrm{Bu}$ farkın hangi gruplar arasında olduğunu belirlemek amacıyla gerçekleştirilen Mann-Whitney U ikili karşılaştırma testi sonuçlarında üniversite düzeyinde öğrenim gören katılımcıların Suriyelilere yönelik kabul etme puanlarının, ilkokul, ortaokul ve lise düzeyinde öğrenim gören katılımcıların puanlarına göre anlamlı düzeyde daha yüksek olduğu tespit edilmiştir. Ayrıca ilkokul ve lise düzeyinde öğrenim gören katılımcıların Suriyelileri tehdit olarak görme puanları, ortaokul düzeyinde öğrenim gören katılımcıların puanlarına göre anlamlı düzeyde daha yüksektir. Üniversite düzeyinde öğrenim gören katılımcıların yerel halkın Suriyelilere yönelik tutum puanları, ilkokul ve ortaokul düzeyinde öğrenim gören katılımcıların puanlarına göre anlamlı düzeyde daha yüksektir.

Öğrenim düzeyinde karışımıza çıkan bu farklılık dişında katılımcıların mesleği ile Suriyelilere yönelik tutumu arasında da anlamlı bir fark tespit edilmiştir. Bu çalışmada kendisini kamuda çalışıp memur, öğretmen, din görevlisi, psikolog, hemşire, askeri personel, belediye veya emniyet personeli olarak tanıtan katılımcılar kamu çalışanı; işçi, esnaf, garson, marangoz, aşçı, terzi, tornacı, demirci, şoför ve ayakkabıcı gibi mesleklerle tanıtan katılımcılar da özel sektör çalışanı olarak kodlanmıştır. Diğer katılımcılar ise kendilerini serbest meslek sahibi, ev hanımı, öğrenci, mesleği yok veya emekli olarak tanitmiştır. 
Tablo 4

Yerel Halkın Suriyelilere Yönelik Tutum Puanlarının Mesleğe Göre Karşılaştırılması

\begin{tabular}{|c|c|c|c|c|c|c|c|}
\hline Ölçek & Meslek & n & $\overline{\mathrm{X}}$ & SS & $\mathrm{X}^{2}$ & $\mathbf{p}$ & Anlamlı Fark \\
\hline \multirow{6}{*}{ Kabul Etme } & A-Kamu çalışanı & 26 & 2,58 & 1,05 & \multirow{6}{*}{22,99} & \multirow{6}{*}{0,000} & $\mathbf{A}>\mathbf{B}, \mathbf{C}, \mathrm{D}, \mathbf{E}, \mathbf{F}$ \\
\hline & B-Özel sektör çalışanı & 157 & 1,64 & 0,78 & & & $\mathbf{C}, \mathbf{E}>\mathbf{B}, \mathbf{D}$ \\
\hline & C-Serbest meslek & 57 & 2,01 & 1,06 & & & \\
\hline & D-Ev hanımı & 71 & 1,64 & 0,73 & & & \\
\hline & E-Öğrenci & 47 & 2,01 & 0,99 & & & \\
\hline & F-Mesleği yok/emekli & 47 & 1,70 & 0,68 & & & \\
\hline \multirow{6}{*}{$\begin{array}{l}\text { Tehdit Olarak } \\
\text { Görme }\end{array}$} & A-Kamu çalışanı & 26 & 2,86 & 1,00 & \multirow{6}{*}{12,67} & \multirow{6}{*}{0,005} & $\mathbf{B}, \mathbf{C}, \mathbf{D}, \mathbf{F}>\mathbf{A}$ \\
\hline & B-Özel sektör çalışanı & 157 & 3,61 & 1,25 & & & \\
\hline & C-Serbest meslek & 57 & 3,66 & 1,19 & & & \\
\hline & D-Ev hanımı & 71 & 3,73 & 1,03 & & & \\
\hline & E-Öğrenci & 47 & 3,38 & 1,02 & & & \\
\hline & F-Mesleği yok/emekli & 47 & 3,92 & 0,98 & & & \\
\hline \multirow{6}{*}{ Reddetme } & A-Kamu çalışanı & 26 & 2,48 & 1,06 & \multirow{6}{*}{8,40} & \multirow{6}{*}{$\mathbf{0 , 0 3 8}$} & $\mathbf{B}, \mathrm{C}, \mathrm{D}, \mathrm{F}>\mathrm{A}$ \\
\hline & B-Özel sektör çalışanı & 157 & 3,08 & 1,31 & & & \\
\hline & C-Serbest meslek & 57 & 3,15 & 1,31 & & & \\
\hline & D-Ev hanımı & 71 & 3,36 & 1,11 & & & \\
\hline & E-Öğrenci & 47 & 3,06 & 1,31 & & & \\
\hline & F-Mesleği yok/emekli & 47 & 3,26 & 1,06 & & & \\
\hline \multirow{6}{*}{ TOPLAM } & A-Kamu çalışanı & 26 & 3,08 & 0,84 & \multirow{6}{*}{17,35} & \multirow{6}{*}{0,001} & $\mathrm{~A}>\mathrm{B}, \mathrm{C}, \mathrm{D}, \mathbf{E}, \mathbf{F}$ \\
\hline & B-Özel sektör çalışanı & 157 & 2,32 & 0,91 & & & \\
\hline & C-Serbest meslek & 57 & 2,40 & 1,03 & & & \\
\hline & D-Ev hanımı & 71 & 2,18 & 0,73 & & & \\
\hline & E-Öğrenci & 47 & 2,53 & 0,90 & & & \\
\hline & F-Mesleği yok/emekli & 47 & 2,17 & 0,76 & & & \\
\hline
\end{tabular}

Suriyelilere yönelik kabul etme $\left(X^{2}=22,99 ; p<0,05\right)$, tehdit olarak görme $\left(X^{2}=12,67 ; p<0,05\right)$, reddetme $\left(X^{2}=8,40 ; p<0,05\right)$ alt boyut puanları ve Suriyelilere yönelik tutum ölçek puanlarının $\left(X^{2}=17,35 ; \mathrm{p}<0,05\right)$ katılımcıların mesleğine göre anlamlı farklılık gösterdiği tespit edilmiştir. Farkın hangi gruplar arasında olduğunu belirlemek amacıyla gerçekleştirilen Mann-Whitney U ikili karşılaştırma testi sonuçlarına göre kamu çalışanı katılımcıların Suriyelilere yönelik kabul etme puanları, diğer meslek gruplarındaki katılımcıların puanlarına göre anlamlı düzeyde daha yüksektir. Serbest meslek ve mesleği olmayan/emekli katılımcıların Suriyelilere yönelik kabul etme puanları, özel sektör çalışanı ve ev hanımı katılımcıların puanına göre anlamlı düzeyde daha yüksektir. Özel sektör çalışanı, serbest meslek, ev hanımı ve mesleği olmayan/emekli katılımcıların Suriyelilere yönelik tehdit olarak görme ve reddetme puanları, kamu çalışanı katılımcıların puanlarına göre anlamlı düzeyde daha yüksektir. Kamu çalışanı olan katılımcıların Suriyelilere yönelik tutum puanları, diğer meslek gruplarındaki katılımcıların puanlarına göre anlamlı düzeyde daha yüksektir. 
Yerel halkın Suriyelilere yönelik tutum puanında anlamlı farklılık tespit edilen bir diğer sosyodemografik değişken katılımcıların aylık geliridir.

Tablo 5

Yerel Halkın Suriyelilere Yönelik Tutum Puanlarının Aylık Gelire Göre Karşılaşstırılması

\begin{tabular}{|c|c|c|c|c|c|c|c|}
\hline Ölçek & Aylık Gelir & n & $\overline{\mathrm{X}}$ & SS & $\mathrm{X}^{2}$ & p & Anlamlı Fark \\
\hline \multirow{5}{*}{ Kabul Etme } & A-1000TL ve alt1 & 133 & 1,76 & 0,86 & \multirow{5}{*}{18,38} & \multirow{5}{*}{0,001} & $\mathbf{E}>\mathbf{A}, \mathbf{B}, \mathbf{C}$ \\
\hline & B-1001-2000TL & 52 & 1,71 & 0,78 & & & \\
\hline & C-2001-3000TL & 159 & 1,71 & 0,86 & & & \\
\hline & D-3001-4000TL & 37 & 2,01 & 0,82 & & & \\
\hline & E-4001TL ve üstü & 24 & 2,55 & 1,14 & & & \\
\hline \multirow{5}{*}{$\begin{array}{l}\text { Tehdit Olarak } \\
\text { Görme }\end{array}$} & A-1000TL ve alt1 & 133 & 3,71 & 1,10 & \multirow{5}{*}{5,87} & \multirow{5}{*}{0,209} & \\
\hline & B-1001-2000TL & 52 & 3,61 & 1,12 & & & \\
\hline & C-2001-3000TL & 159 & 3,61 & 1,21 & & & \\
\hline & D-3001-4000TL & 37 & 3,37 & 1,13 & & & \\
\hline & E-4001TL ve üstü & 24 & 3,22 & 1,16 & & & \\
\hline \multirow{5}{*}{ Reddetme } & A-1000TL ve alt1 & 133 & 3,28 & 1,20 & \multirow{5}{*}{8,81} & \multirow{5}{*}{0,066} & \\
\hline & B-1001-2000TL & 52 & 3,03 & 1,35 & & & \\
\hline & C-2001-3000TL & 159 & 3,17 & 1,23 & & & \\
\hline & D-3001-4000TL & 37 & 2,76 & 1,26 & & & \\
\hline & E-4001TL ve üstü & 24 & 2,66 & 1,14 & & & \\
\hline \multirow{5}{*}{ TOPLAM } & A-1000TL ve alt1 & 133 & 2,26 & 0,84 & \multirow{5}{*}{11,48} & \multirow{5}{*}{$\mathbf{0 , 0 2 2}$} & $E>A, B, C$ \\
\hline & B-1001-2000TL & 52 & 2,35 & 0,90 & & & \\
\hline & C-2001-3000TL & 159 & 2,31 & 0,90 & & & \\
\hline & D-3001-4000TL & 37 & 2,63 & 0,92 & & & \\
\hline & E-4001TL ve üstü & 24 & 2,89 & 1,01 & & & \\
\hline
\end{tabular}

Suriyelilere yönelik kabul etme $(X 2=18,38 ; \mathrm{p}<0,05)$ tehdit alt boyut puanları ve Suriyelilere yönelik tutum ölçek puanlarının (X2=11,48; $\mathrm{p}<0,05)$ katılımcıların aylık gelirine göre anlamlı farklılık gösterdiği tespit edilmiştir. Farkın hangi gruplar arasında olduğunu belirlemek amacıyla gerçekleştirilen Mann-Whitney U ikili karşılaştırma testi sonuçlarına göre aylık geliri $4001 \mathrm{TL}$ ve üstü olan katılımcıların Suriyelilere yönelik kabul etme ve tutum puanları, aylık geliri 3000 TL ve altı olan katılımcıların puanlarına göre anlamlı düzeyde daha yüksektir. Buna karşın yerel halkın Suriyelilere yönelik tehdit olarak görme ve reddetme tutum puanlarının katılımcıların aylık gelirine göre anlamlı farklılık göstermediği ( $p>0,05)$ tespit edilmiştir. Son olarak yerel halkın Suriyelilere yönelik tutum puanları arasındaki ilişki incelenmiştir. 
Tablo 6

Suriyelilere Yönelik Tutum Puanları Arasındaki İlişki

\begin{tabular}{|l|c|c|c|}
\hline Alt Boyut & $\mathbf{2}$ & $\mathbf{3}$ & $\mathbf{4}$ \\
\hline 1-Kabul Etme & $-0,43^{* *}$ & $-0,49^{* *}$ & $0,69^{* *}$ \\
\hline 2-Tehhdit Olarak Görme & 1 & $0,66^{* *}$ & $-0,86^{* *}$ \\
\hline 3-Reddetme & & 1 & $-0,86^{* *}$ \\
\hline 4-TOPLAM & & & 1 \\
\hline
\end{tabular}

Spearman's Rho korelasyonu analizi sonuçlarına göre Suriyelilere yönelik kabul etme alt boyut puanları ile tehdit olarak görme $(\mathrm{r}=-0,43 ; \mathrm{p}<0,05)$ ve reddetme $(r=-0,49 ; p<0,05)$ puanları arasında negatif yönlü ve anlamlı ilişki tespit edilmiştir. Suriyelilere yönelik kabul etme puanı yüksek olan katılımcıların, tehdit olarak görme ve reddetme puanları düşük düzeydedir. Suriyelilere yönelik tehdit olarak görme alt boyut puanları ile reddetme puanları arasında pozitif yönlü ve anlamlı ilişki tespit edilmiştir $(r=0,69 ; \mathrm{p}<0,05)$. Suriyelilere yönelik tehdit olarak görme puanı yüksek olan katılımcıların, reddetme puanları düşük düzeydedir.

\section{Tartışma}

Kahramanmaraş'taki yerel halkın Suriyelilere yönelik tutumunda altı farklı sosyodemografik değişkenin (cinsiyet, medeni durum, yaş, gelir getirici bir işte çalışma durumu, ailedeki kişi sayısı ve memleket) anlamlı düzeyde bir etkisinin bulunmadığ tespit edilmiştir. Bu çalışma özelinde cinsiyete göre herhangi bir farklılığın bulunmuyor olması önemlidir; çünkü Türkiye'nin farklı illerinde yapılan çalışmalarda katılımcıların cinsiyeti ile Suriyelilere yönelik algı ve tutum düzeyleri arasında anlamlı bir farkın bulunduğu anlaşılmaktadır (Saçan, Cizdan ve Tabak 2017; Yılmaz, 2017; Ankaralı, Pasin, Karacan, Tokar, Künüroğlu, Çaça, Özislam ve Şahingöz, 2017). Yapılan araştırmalarda Kilis, Gaziantep, Şanlıurfa, Hatay ve Adana (Yılmaz, 2017) illerindeki kadınların erkeklere oranla; Aydın (Saçan, Cizdan ve Tabak 2017) ve Düzce (Ankaralı vd., 2017) illerindeki erkeklerin de kadınlara oranla Suriyelilere yönelik daha olumsuz bir algıya ve tutuma sahip oldukları tespit edilmiştir. Bu araştırmada Kahramanmaraş'a yakın illerde (Kilis, Gaziantep, Şanlıurfa, Hatay ve Adana) olduğu gibi cinsiyetler arasında anlamlı bir farkın ortaya çıkmamış olması, kadınların bu araştırmaya (\%37) katılım oranının erkeklere oranla (\%63) daha düşük olması ile açıklanabilir.

Bu araştırmada anlamlı farkın ortaya çıkmadığı diğer değişken gelir getirici bir işte çalışma durumudur. Bu değişken özelinde gelir getirici bir işte çalışan katılımcılar ile çalışmayan (işsiz olan) katılımcıların Suriyelilere yönelik 
tutumunda anlamlı bir fark bulunmamaktadır. Oysaki gerek medyada yer alan haberlerde (Göker ve Keskin, 2015) gerekse akademik çalışmalarda (Erdoğan, 2014; Oytun ve Gündoğar, 2015; Taştan, Haklı ve Osmanoğlu, 2017; Woods ve Kayalı, 2017; Sönmez ve Adıüzel, 2017; Ekici, 2019) Suriyelilerin yerel halkın işsizliğinden sorumlu tutulduğu ileri sürülmektedir. Örneğin Ankara' da yapılan bir araştırmada Suriyelilere yönelik ekonomi ile ilgili tehdit algısı ilk sırada yer almaktadır (Taştan, Haklı ve Osmanoğlu, 2017). Bu araştırmada, Suriyelilerin işsizlik oranlarında artışa neden olduğunu düşünen katılımcıların oranı \%86,6'dır. Benzer şekilde İstanbul (Woods ve Kayalı, 2017), Elazığ (Budak, 2017), Hatay, Gaziantep, Mardin ve Urfa (Erdoğan, 2014) gibi illerde de yerel halk, işsizlik sorunu ile doğrudan Suriyelileri ilişkilendirmektedir. 2020 yılının son çeyreğinde, Covid-19 pandemi sürecinde, Kahramanmaraş'ta gerçekleştirilen bu araştırmada katılımcıların gelir getirici bir işte çalışıp çalışmıyor olmalarının Suriyelilere yönelik tutumlarında herhangi bir farka yol açmadığı tespit edilmiştir. Ancak gelir getirici bir işte çalışanlarla, gelir getiren bir işte çalışmayanlar (işsiz olanlar) arasında tutum konusunda anlamlı bir fark olmaması gelir getiren bir işte çalışmayanların işsizlik yüzünden Suriyelileri suçlamadıkları ya da suçlamayacakları olarak değerlendirilmemelidir. Üstelik gelir getirici bir işte çalışanların da işsizlik ile ilgili olarak Suriyelileri suçlayabilecekleri ihtimali göz ardı edilmemelidir. Bu sonuçta Covid-19 pandemisinin pek çok insanın işini kaybetmesine veya bir süreliğine işine ara vermesine neden olmuş ya da oluyor olması etkili olabilir. Bir başka ifadeyle yerel halkın işsiz olmalarının ya da işsiz kalmalarının nedenini Suriyelilere bağlamak yerine Covid-19 pandemisine bağlamayı tercih ettikleri ileri sürülebilir. Dolayısıyla yerel halkın son zamanlarda yaşanan küresel gelişmelere bağlı olarak Suriyelilerin işlerini ellerinden aldıkları düşüncesinden uzaklaşmış olabilecekleri iddia edilebilir. Nitekim 2019 yılında Türkiye genelinde gerçekleştirilen bir araştırmada katılımcılara "Son 5 yl içinde Suriyelilerden zarar gördünüz mü? ” sorusu yöneltilmiştir. Bu soruya evet olarak cevap verenlere "Nasıl bir zarar gördünüz?" sorusu yöneltilmiş ve katılımcıların sadece \%6,4'ü “iş kaybı” olarak cevap vermiştir (Erdoğan, 2020). Bu araştırmada “iş kaybı” zarar görme nedenleri içinde altıncı sırada yer almıştır. 2020 yılı Temmuz ayı verilerine göre Türkiye'de işsizlik oranları \%13,7’ye gerilerken, genç işsizlik oranı \%25,9'a yükselmiştir (TUİK, 2020). Her ne kadar istihdam bekleyen Türkiye Cumhuriyeti vatandaşlarının sayısı 4,5 milyona ulaşmış olsa da bu niceliksel artışın -bazı sınır illerindeki istisnai durumlar dışındaSuriyelilerden kaynaklandığını söylemek gerçekçi olmayacaktır (Erdoğan, 2020). 
Katılımcıların öğrenim düzeyi ile Suriyelilere yönelik tutumları arasında anlamlı bir fark bulunduğu tespit edilmiştir. Üniversite düzeyinde öğrenim gören katılımcıların hem kabul etme hem de tutum puanları ilkokul, ortaokul ve lise düzeyinde öğrenim gören katılımcılara oranla daha yüksektir. Bu sonuçlardan hareketle üniversite öğreniminin farklılıklara sayg1, farkl111kları kabul ve farklılıklarla uyum gibi konularda geliştirici ve eğitici olduğu söylenebilir. Fakat Türkiye'de üniversite öğrencileri arasında yapılan bazı araştırmalarda üniversite öğrencilerinin Suriyelilere yönelik olumsuz tutumlara katıldıkları ve Suriyelilerin varlıklarını bir tehdit olarak algıladıkları tespit edilmiştir (Oytun ve Gündoğar, 2015; Topkaya ve Akdağ, 2016; Ankaralı vd., 2017; Polat ve Kaya, 2017; Şen ve Şimşek, 2019). Buna göre gruplararası farklılıklarda üniversite düzeyinde öğrenim gören katılımcıların ilkokul, ortaokul ve lise düzeyinde öğrenim gören katılımcılara göre yüksek düzeyde olumlu tutuma sahip olabileceği; ancak grup içi değerlendirmelerde Suriyelilere yönelik tutumun daha olumsuz olduğu anlaşılmaktadır. Türkiye' deki üniversite öğrencilerinin Suriyelilere yönelik tutumunda Suriyeli bir arkadaşa sahip olma, gündelik yaşamda Suriyelilerle ilişki kurma, kendini güvende hissetme gibi faktörlerin olumlu bir etkiye sahip olduğu görülmektedir (Şen ve Şimşek, 2019). Ayrıca üniversitelerin eğitim müfredatlarında göçmen ve sığınmacılara yönelik derslerin bulunuyor olmasının da öğrencilerin tutumlarını olumlu yönde değiştirdiği ve geliştirdiği tespit edilmiştir (Kırlığlu ve Gencer, 2020).

Katılımcıların gelir getirici bir işte çalışıp çalışmama durumları Suriyelilere yönelik tutumlarında herhangi bir farklılı̆ga yol açmasa da sahip oldukları meslekler arasında anlamlı bir fark bulunmaktadır. Buna göre kamu sektöründe çalışan katılımcıların Suriyelilere yönelik kabul etme puanları diğer sektörlerde çalışan ya da çalışmayan (mesleği olmayan/emekli/öğrenci) katılımcıların puanlarına göre anlamlı düzeyde daha yüksektir. Bu durumun nedenini açıklamak için kamu sektöründe çalışan katılımcıların gündelik hayatta Suriyeliler ile daha çok karşılaştıkları, diğer katılımcılara göre düzenli bir ekonomik gelire ve daha iyi bir sosyal statüye sahip oldukları ileri sürülebilir. Toplumdaki gruplararası temasın az olmas1, insanların ekonomik olarak düzensiz bir gelire ve toplumsal alanda düşük bir statüye sahip olması ya da herhangi bir statüye sahip olamaması zaman zaman başka/diğer insanların/ grupların suçlanmasına yol açabilmektedir. Literatürde "günah keçisi" (Campbell, 2020), "olağan şüpheliler" (Man, 2016) ya da "yabanc1lar/onlar" (Bauman, 2014) olarak tanımlanan bu insanlara/gruplara yönelik olumsuz alg1 
ve tutumlar yüzlerce yıldır pratik edilmektedir. Örneğin Charlie Campbell (2020) "günah keçisi” kavramının ilk olarak 16. yüzyılda yayınlanan bir İncil çevirisinde kullanıldığını ve işlerin yolunda gitmediği zamanlarda azınlık veya marjinal insanları/grupları hedef alan bir işleve sahip olduğunu ileri sürmektedir. Bu kavramın geçmişte kadınlardan engellilere, Romanlardan Yahudilere kadar pek çok kullanım örneği bulunmakla birlikte günümüzde en çok göçmen, sığınmacı ve mülteci nüfusu tanımlamak için tercih edildiği görülmektedir. "Dostlar var, düşmanlar var. Bir de yabancılar" diyerek kategoriler üzerinden modernliğin nasıl işlevsel hale getirildiğini açıklamaya çalışan Bauman'ın (2014) ifadeleri tam olarak bu duruma karşıllı gelmektedir. Neo-liberal politikalarla şekillenen özel sektörün emek üzerindeki yoğun sömürüsü ve göç ile gelen nüfusun "yedek işgücü/sanayi ordusu” (Marx, 2015) olarak işçi sınıfının üzerinde oluşturduğu baskı kamusal güvenceden yoksun olarak çalışan ya da çalışmayan (mesleği olmayan/emekli/öğrenci) katılımcıların tutum puanını etkilemiş olabilir.

Türkiye'de yapılan araştırmalar incelendiğinde doğrudan meslekler üzerinden bir algı ve tutum araştırması yapılmadığı görülmektedir. Ancak farklı amaçlarla yapılan bazı akademik çalışmalarda farklı meslek gruplarında yer alan kişilerin görüşlerine rastlanmaktadır. Örneğin Bolu'da yapılan nitel bir araştırmada esnaf ve serbest meslek sahibi olan katılımcıların Suriyelilere yönelik olumsuz alg1 ve tutuma sahip oldukları görülmektedir (Güney ve Konak, 2016). Benzer şekilde Kahramanmaraş’ta yapılan bir başka araştırmada da esnaf olan katılımcılar Suriyelilere yönelik olumsuz alg1 ve tutumlara sahiptir (Aydın ve Durgun, 2018). Bu araştırmada esnaf olan katılımcıların görüşleri özel sektör çalışanı kategorisinde değerlendirilmiştir. Bu grup içinde yer alan katılımcıların da Suriyelilere yönelik tutum ve kabul etme puanları düşük düzeydedir. Dolayısıyla bu araştırma sonuçlarının da daha önce Bolu (2016) ve Kahramanmaraş (2018) illerinde yapılan araştırma sonuçlarına benzer olduğu ifade edilebilir. Bolu'daki esnafin ve yerel halkın Suriyelilere yönelik olumsuz alg1 ve tutumları sadece araştırma sonuçlarına değil; 2019 yılında gerçekleşen yerel seçimlerin propaganda süreçlerine ve sonuçlarına da yansımıştır (Euronews, 2019; Deutsche Welle Türkçe, 2020). Benzer şekilde ulusal ve yerel basında yer alan haberler incelendiğinde (Hürriyet, 2014; Haber46, 2020) özellikle esnaf ve serbest meslek sahibi olan yerel halkın Suriyelilere yönelik olumsuz algı ve tutumlarına Kahramanmaraş ilinde de rastlanmaktadır. 
Yerel halkın meslekleri dışında aylık gelir durumları da Suriyelilere yönelik tutumlarını etkilemektedir. Aylık geliri 3000 TL ve altı olan katılımcıların Suriyelilere yönelik kabul etme ve tutum puanları aylık geliri 4001 TL ve üstü olan katılımcılara oranla daha düşüktür. 2020 yılı sonunda asgari ücretin net 2324 TL 70 kuruş olduğu göz önüne alındığında; sadece asgari ücret ve altında gelir sahibi olan katılımcıların değil aynı zamanda asgari ücretin üçte birinden daha fazla gelire sahip olan katılımcıların da Suriyelilere yönelik kabul etme ve tutum puanlarının düşük olduğu anlaşılmaktadır. Ekonomik gelirin az olması ya da olmaması insanların duygu, düşünce ve davranışları üzerinde oldukça önemli bir etkiye sahiptir. Özellikle sürekli çalışma ve tüketme anlayışı üzerine inşa edilmiş olan tüketim toplumunda bu etki daha çok hissedilmektedir. Yapılan araştırmalarda bu etkinin genellikle olumsuz yönde olduğu görülmektedir (Kurt, 2006; Bakan, Akyüz, Eyitmiş ve Doğan, 2011; Pezirkianidis, Stalikas, Efstathiou ve Karakasidou, 2016). Dolayısıyla düşük aylık gelir düzeyine sahip olan katılımcıların Suriyelilere yönelik kabul etme ve tutum puanlarının düşük düzeyde tespit edilmesi beklenen bir sonuçtur. Türkiye'de Sığınmacılar ve Göçmenlerle Dayanışma Derneği (SGDD) tarafından yapılan ve yerel halkın aylık gelir düzeyleri ile sığınmacı/mültecilere yönelik alg1 ve tutumunun karşılaştırıldığı bir araştırmada da benzer sonuçlara ulaşılmıştır (SGDD, 2011). SGDD’nin bu araştırmasında katılımcıların aylık ortalama gelirleri ile sı̆̆ınmacı ve mültecilere yönelik olumlu algıları arasında pozitif bir ilişki tespit edilmiştir. Buna göre, gelir düzeyi arttıkça olumlu algı ve tutum da artmakta; gelir düzeyi azaldıkça olumlu algı ve tutum da azalmaktadır (SGDD, 2011). Türkiye'de yapılan bir başka araştırmada da gelir düzeyi düşük olan katılımcılar, gelir düzeyi yüksek olanlara oranla Suriyelilerden daha çok kaygı duymaktadır (Demir, 2015). İstanbul' da yapılan bir çalışmaya göre yerel halkın Suriyelilere yönelik ekonomik tehdit algısı gelir seviyesine göre değişmekte; gelir seviyesi arttıkça ekonomik tehdit alg1 ortalaması azalmaktadır (İstanbul Politik Araştırmalar Enstitüsü, 2020). Benzer şekilde Hatay, Adana, Gaziantep, Şanlıurfa ve Kilis illerinde yapılan bir araştırmada da yerel halkın Suriyelilerden rahatsızlık duyma durumunun aylık ortalama gelir değişkeninden bağımsız olmadığı sonucuna ulaşılmıştır (Yılmaz, 2017). Bu kaygı ve rahatsızlık duyma durumu dolaylı olarak yerel halkın duygu, düşünce ve davranışına etki etmekte; Suriyelilere yönelik algı ve tutumu da şekillendirmektedir. Fakat burada yerel halkın Suriyelilere yönelik algı ve tutumunun sadece aylık gelir düzeyi ile ilgili olmadığı; aylık gelir düzeyine eşlik eden farklı faktörlerin de bulunduğu göz 
ardı edilmemelidir. Örneğin Almanya'da bulunan Türkiye Cumhuriyeti vatandaşlarının Suriyelilere yönelik tutumlarının araştırıldığ 1 bir çalışmada katılımcıların aylık gelir düzeyleri ile Suriyelilere yönelik tutumları arasında anlamlı bir fark tespit edilmemiştir (Ayvaz, 2019).

Analiz sonuçlarına göre Suriyelilere yönelik tehdit olarak görme puanı yüksek olan katılımcıların reddetme puanları da yüksek düzeydedir. Mültecilere ve sığınmacılara yönelik olumsuz algı ve tutumların temelde tehdit algısı ile ilişkili olduğu ve gruplar arası çatışmaların bu tehdit algıları etrafında şekillendiği öne sürülmektedir (Riek, Mania ve Gaertner, 2006; Murray ve Marx, 2013; Ekici, 2019). Yeni gelenlerin (göçmen, sığınmacı ve/veya mülteci) reddedilmesine yol açan bu tehdit algısının sosyal, kültürel, ekonomik, güvenlik ve temel hizmetlere erişim tehdidi gibi farklı değişkenler tarafından şekillendirilen alt boyutları bulunmaktadır (Ekici, 2019). Türkiye'de Suriyelilere yönelik oluşan tehdit algılarının; Suriyelilerin ucuz/yedek işgücü olarak istihdam piyasasındaki varlığı (Erdoğan, 2014), Suriyeliler için yapılan harcamalar ve ekonomik yardımlar (Polat ve Kaya, 2017), Suriyelilerin vatandaş olmamalarına rağmen Türkiye'nin kaynaklarından yararlanıyor oldukları düşüncesi (Kahraman ve Nizam, 2016), başta sağlık ve eğitim hizmetleri olmak üzere yerel halkın temel hizmetlere erişimde yaşadığı zorluklar (Marmara Belediyeler Birliği, 2015) ve uzun süreli/süren misafirperverlik sonucu oluşan belirsizlik (Ekici, 2019) gibi çeşitli nedenleri bulunmaktadır. Bu nedenler göz önüne alındığında yukarıda bahsi geçen farklı türde tehdit algılarının Türkiye'de bulunan Suriyeliler özelinde de gerçekleşmiş olduğu ifade edilebilir. Yerel halkın Suriyelileri tehdit olarak görmesi de beraberinde reddetme, dışlama ve ötekileştirme pratiklerinin gelişmesine ortam hazırlamaktadır. Bu tehdit algılarının yaygınlaşması ve Suriyelilerin yerel halk tarafından dışlanması/ reddedilmesi sürecinde ulusal ve sosyal medyanın etkisi ve önemi göz ardı edilmemelidir (Oytun ve Gündoğar, 2015).

Öte yandan Suriyelilere yönelik kabul etme puanı yüksek olan katılımcıların, Suriyelileri tehdit olarak görme ve reddetme puanları da düşük düzeydedir. Burada yerel halkta Suriyelilere yönelik oluşan kabul etme durumu, olumlu tutumun gelişmesine ve birlikte yaşam idealine ulaşılmasında oldukça önemlidir. Aynı ölçek kullanılarak gerçekleştirilen bir araştırmada yerel halkın Suriyelileri kabul etme, tehdit olarak görme ve reddetme düzeyleriyle ilgili toplam puanlarının Suriyeliler ile karşılaşma sıklıkları, tanışık olma durumları, bireysel 
ve yakın çevrede sorun yaşama pratikleri ile yakından ilişkili olduğu tespit edilmiştir (Yiğit Özüdoğru ve Kan, 2020). Buna göre; Suriyelilerle etkileşim (tanışık olma, konuşma, görüşme, iş yapma) içinde olan yerel halkın Suriyelilere yönelik kabul etme düzeyinin daha yüksek; etkileşim içinde olmayan ya da sorun yaşayanların ise tehdit olarak görme ve reddetme düzeylerinin daha yüksek olduğu anlaşılmaktadır (Yiğit Özüdoğru ve Kan, 2020). Bu noktada bireyler ya da gruplar arasındaki olumlu veya olumsuz temas durumu ön plana çıkmaktadır. Bu konuyla ilgili literatür incelendiğinde 1950'li yıllarda geliştirilen gruplararası temas hipotezi ${ }^{4}$ karşımıza çıkmaktadır (Allport, 1954). Bu hipoteze göre farklı grupların ya da kişilerin birbirleriyle etkileşime girmesi, birbirlerini tanıması veya birbirleri hakkında bilgi edinmesi önyargıları azaltacaktır. İki grup ya da kişi arasındaki temas ne kadar artarsa, önyargılar da azalacaktır (Allport, 1954). Öte yandan temas ne kadar azalırsa gruplar ya da kişiler arası önyargılar artacak; algı ve tutumlar olumsuz yönde gelişecektir. Benzer şekilde Yiğit Özüdoğru ve Kan (2020) tarafından gerçekleştirilen araştırmanın sonuç bölümünde temassız karşılaşma sıklığının artmasının, yerel halkın Suriyelilere karşı daha olumsuz tutum içerisinde olmasına yol açtı̆̆ına vurgu yapılmaktadır. Dolayısıyla gruplar ya da kişiler arasındaki etkileşimli temas, hem yerel halkın hem de Suriyelilerin birbirlerine karşı daha olumlu bir tutum içerisinde bulunmasına, işbirliği ağlarının oluşmasına ve birlikte yaşama kültürünün gelişmesine katkı sağlayacaktır. Nitekim Türkiye'de yapılan bir araştırma (Eşigül, Arslan, Gencer, Tosun, Korkmaz ve Yıldırım, 2017) Suriyelilerle etkileşim içinde olan bireylerin, birlikte yaşama idealine sadece karşılaşma ile yetinenlere oranla daha yakın olduğunu ortaya koymaktadır.

\section{Sonuç ve Öneriler}

Son yıllarda Suriye'den Türkiye'ye gelen ve sığınma talebinde bulunanların sayısı azalsa da Suriye'deki iç karışıklık ve güvensiz ortam varlığını sürdürmektedir. Bu durum Suriye'den gelenlerin geri dönüşlerini zorlaştırmakla kalmıyor; aynı zamanda yeni doğanların ve Türkiye'de büyüyenlerin kendilerini bu topraklara ait hissetme duygularını da pekiştiriyor. 2011 yılından bugüne kadar geçen süre; sığınmacılıktan misafirliğe, misafirlikten geçici korumaya, geçici korumadan da yerleşik olma haline doğru evrilmiştir. Yerleşik olmanın vatandaşlık ile resmiyet kazanacağı bir gelecekte, yerel halk ile Suriye kökenli olan vatandaşların bir arada yaşamalarına yönelik çalışmalar önem arz

4 intergroup contact hypothesis 
etmektedir. Gelecekte ortaya çıkabilecek muhtemel sorunların bugünden engellenebilmesi ya da minimize edilebilmesi için disiplinler arası ya da ötesi çalışmalara ihtiyaç duyulmaktadır. Fakat bu çalışmaların gerçekleştirilebilmesi için öncelikle gruplararası algı ve tutum çalışmalarının yapılması gerekmektedir. $\mathrm{Bu}$ düşünceden hareketle gerçekleştirilen bu araştırmada; \%8,02'lik oranla Türkiye ortalamasının $(\% 4,37)$ üzerinde Suriyeli nüfusa sahip olan Kahramanmaraş'taki yerel halkın Suriyelilere yönelik tutumu (kabul etme, tehdit olarak görme ve reddetme alt boyutlarıyla) sosyodemografik değişkenler üzerinden incelenmiştir.

Araştırma sonucunda yerel halkın Suriyelilere yönelik tutum puanının düşük düzeyde olduğu açık bir şekilde görülmektedir. Bu çalışma mahiyeti itibariyle bu tespitin nedenselliğini açıklama iddiasında değildir. Buna rağmen sosyodemografik değişkenler üzerinden bir değerlendirme yapıldığında yerel halkın Suriyelilere yönelik tutum puanında ögrenim düzeyi, meslek ve aylık gelir değişkenlerinin belirleyici olduğu anlaşılmaktadır. Bu noktada üniversite eğitimi almamış olan katılımcıların, kamu sektörü dışında çalışan ya da çalışmayanların (mesleği olmayan/emekli/öğrenci), aylık geliri 3000 TL ve altı olan katılımcıların olumsuz tutumları öne çıkmaktadır. Bu araştırma sonuçları ile buraya kadar bahsi geçen diğer çalışmalar bir bütün olarak değerlendirildiğinde; Suriyelilere yönelik olumsuz (düşük düzeyde) algı ve tutumların 2014 yılından bugüne kadar varlığını sürdürdüğü anlaşılmaktadır. Bu süreçte başta İçişleri Bakanlığı'na bağglı Göç İdaresi Genel Müdürlüğü ve AFAD olmak üzere Aile, Çalışma ve Sosyal Hizmetler Bakanlığı, Milli Eğitim Bakanlığı, Gençlik ve Spor Bakanlığı, Kızılay ile çeşitli ulusal ve uluslararası sivil toplum kuruluşlarının farklı çalışmalar gerçekleştirdiği bilinmektedir. Fakat bu çalışmaların daha çok beslenme, barınma, sağlık ve eğitim gibi alanlarda yoğunlaştığı, ihtiyaç temelli müdahaleler içerdiği, özellikle toplumsal/karş11ıklı uyum veya birlikte yaşam gibi konularda etkin olmadığı görülmektedir. 2019 yılından itibaren Göç İdaresi Genel Müdürlüğü tarafından "Uyum Mahalle Buluşmaları" adı altında uyum odaklı faaliyetler gerçekleştirilmeye başlanmıştır. Ancak bu faaliyetlerin farklı çalışmalarla desteklenememesi, bir yerleşim yerindeki tüm mahalleleri kapsayacak şekilde yaygınlaştırılamaması, devam eden Covid-19 pandemi sürecinin yol açtığı sokağa çıkma ya da bir araya gelme yasakları gibi nedenlerden dolayı toplumsal/karşılıklı uyum veya birlikte yaşam gibi konularda henüz istenilen noktaya ulaşılamadığı görülmektedir. 
Göç ile gelen bireylerin yeni geldikleri topluma, kültüre, coğrafyaya ve daha pek çok yerleşik yapıya uyum sağlamaları beklenmektedir. Yerel halk açısından bu son derece haklı bir beklenti olarak kabul edilebilir; ama burada uyumun tek taraflı bir süreç olmadığı da göz ardı edilmemelidir. Dolayısıyla Türkiye'deki Suriyelilerin topluma, kültüre, coğrafyaya uyum sağlamaları için yerel halkın da sürece dâhil olması/edilmesi oldukça önemlidir. Yerel halk ile Suriyeliler arasındaki toplumsal/karşılıklı uyum ve birlikte yaşam pratiğinin sağlanabilmesi için öncelikle her iki tarafa yönelik toplumsal düzeyde "kabullenme ve güven" çalışmalarının yapılması önerilmektedir. Her iki tarafın da birbirlerini kabul etmesi ve birbirlerine güvenmesi bu süreçte öncelikli hedef olmalıdır. $\mathrm{Bu}$ konuyla ilgili olarak yapılan çalışmalar incelendiğinde her iki tarafın da birbirleri hakkında bilgi eksikliğinin bulunduğu ve bu eksikliğin toplumsal/ karşılıklı uyumun ve birlikte yaşamın önündeki büyük bir engel olduğu anlaşılmaktadır. Bunun için her iki tarafın da bir araya gelebileceği ve birbirlerini daha yakından tanıyabileceği ortamların oluşturulması önerilmektedir. $\mathrm{Bu}$ konuda "Uyum Mahalle Buluşmaları" gibi çeşitli sosyal, kültürel veya dini etkinlikler (kermesler, şenlikler, kutlamalar, bayramlaşma veya kandil etkinlikleri gibi) gerçekleştirilebilir. Bu etkinlikler için okul bahçeleri kullanılabilir. Üniversiteler ve/veya sivil toplum kuruluşları ile işbirliği sağlanarak her iki tarafın da birbirlerinin dillerini öğrenebileceği mahalle merkezli dil kursları açılabilir. Bu merkezler için camilerin ya da mescitlerin eğitim için ayrılan bölümleri kullanılabilir. Ayrıca her iki tarafın da birbirleri ile ilgili bilgi alabileceği, iletişim kurabileceği, rahatsızlıklarını veya isteklerini dile getirebileceği yerel irtibat/bilgi edinme bürolarının açılması sağlanabilir. $\mathrm{Bu}$ bürolar için mahalle muhtarlıkları kullanılabilir. Bu bürolar aracılığıyla komşuluk ilişiklerine, komşuluk hakkına ve hukukuna vurgu yapan yazılı, sözlü veya görsel bilgilendirme çalışmaları yapılabilir.

Buraya kadar önerilen uygulamaların tamamı her iki tarafin da sorumluluk alması gerektiğini ortaya koyan yerel ve mahalli düzeydeki uygulamalardır. Bugün yerel halkın yeni gelen bireylere yönelik olumlu algı ve tutum geliştirebilmesi için öncelikle toplumsal/karşılıklı uyum ve birlikte yaşam çalışmalarının gerekli olduğu bilinmektedir. Bu çalışma özelinde de söz konusu çalışmaların yerel ve mahalli düzeyde gerçekleştirilmesi önerilmektedir. Bu süreçte başta valilikler olmak üzere yerel yönetimler, göç idaresi il müdürlükleri, kültür ve turizm il müdürlükleri, müftülükler, yerel basın-yayın kuruluşları, muhtarlıklar ve sivil toplum kuruluşları gibi farklı paydaşlara önemli görevler düşmektedir. 
Etik: Bu araştırma Recep Tayyip Erdoğan Üniversitesi, Sosyal ve Beşerî Bilimler Etik Kurulu'nun 18.08.2020 tarih ve 2020/85 sayılı toplantısında etik açıdan uygun bulunmuştur.

Hakem Değerlendirmesi: Dış bağımsız.

Çıkar Çatışması: Yazar çıkar çatışması bildirmemiştir.

Finansal Destek: Yazar bu çalışma için finansal destek almadığını beyan etmiştir.

Peer-review: Externally peer-reviewed.

Conflict of Interest: The author has no conflict of interest to declare.

Grant Support: The author declared that this study has received no financial support.

\section{Kaynakça/References}

Abadan-Unat, N. (2006). Bitmeyen Göç: Konuk İşçilikten Ulus Ötesi Yurttaşlı̆̆a. (İkinci Basım), İstanbul: Bilgi Üniversitesi Yayınlar1.

Allport, G. W. (1954). The Nature of Prejudice. Cambridge: Addison-Wesley.

Ankaralı, H., Pasin, Ö., Karacan, B., Tokar, M., Künüroğlu, M., Çaça, M., Özislam, M. E. \& Şahingöz, N. B. (2017). Üniversite öğrencilerinin Türkiye'deki Suriyeli sığınmacılara bakış açısı. Düzce Üniversitesi Sağllk Bilimleri Enstitüsü Dergisi, 7(3), 122-132.

Aydın, A. H. \& Durgun, S. (2018). Kahramanmaraş’taki Suriyeli sığınmacıların yerel halk tarafından sosyo-ekonomik ve politik açıdan değerlendirilmesi. Kahramanmaraş Sütçü İmam Üniversitesi Sosyal Bilimler Dergisi, 15 (2), 501-526.

Ayvaz, Ş. (2019). Berlin'deki Türk Göçmenlerin Suriyeli Mültecilere Yönelik Görüş ve Tutumları Üzerine Bir Çalışma: Berlin/Almanya Örneği, Yüksek Lisans Tezi, Ankara: Hacettepe Üniversitesi Sosyal Bilimler Enstitüsü.

Bakan, İ., Akyüz, M., Eyitmiş, A. M., \& Doğan, İ. F. (2011). Ekonomik Krizin İnsan Davranışları Üzerine Etkilerine Yönelik Malatya'da Bir Alan Çalışması. Bingöl Üniversitesi Sosyal Bilimler Enstitüsü Dergisi, 1(1), 1-24.

Bauman, Z. (2014). Modernlik ve Müphemlik, (Çev. İsmail Türkmen), İstanbul: Ayrıntı Yayınlar1.

Brüß, J. (2003). Mutual acceptance or rejection? Exploring social distance among German, Turkish and Resettler adolescents. Immigration in Europe: Issues, Polities and Case Studies. Bilbao, 207-225.

Budak, P. (2017). Yerel halkın algısında Suriyeli sığınmacılar ve toplumsal etkileri: Elazı̆̆ ili örneği. Akademik Sosyal Araştırmalar Dergisi, 5 (62), 543-564.

Büyüköztürk, Ş. (2019). Sosyal Bilimler Iç̧in Veri Analizi El Kitabı (25. Baskı). Ankara: PEGEM Akademi Yayınları.

Castles, S., \& Miller, M. (2008). Göçler çağı: Modern dünyada uluslararası göç hareketleri. İstanbul Bilgi Üniversitesi.

Cengiz, D. (2015). Zorunlu Göçün Mekânsal Etkileri ve Yerel Halkın Algısı; Kilis Örneği. Electronic Turkish Studies, 10 (2), 101-122.

Champion, A. G. (1994). International migration and demographic change in the developed world. Urban Studies, 31(4-5), 653-677. 
Çalışkan, S. (2019). Ev Sahibi Halkın Suriyeli Göçmenlere Yönelik Tutumu: İstanbul; Sultanbeyli-Kadıköy İlçeleri, Journal of International Social Research, 12 (66), 640650.

Çaro, E., \& Van Wissen, L. J. G. (2008). Migration in the Albania of the post-1990s: triggered by post-communist transformations and facilitator of socio-demographic changes. SEER Journal for Labour and Social Affairs in Eastern Europe, 10(3), 87105.

Çetin, S. (2017). İzmir'deki Yerel Halkın Suriyeli Sığınmacılara Yönelik Algısı (Yüksek Lisans Tezi), Afyon Kocatepe Üniversitesi Sosyal Bilimler Enstitüsü.

Campbell, C. (2020). Günah Keçisi: Başkalarını Suçlamanın Tarihi, (Çev. Gizem Kastamonulu), İstanbul: İthaki Yayınları

Demir, O. Ö. (2015). Göç politikaları, toplumsal kaygılar ve Suriyeli mülteciler. Global Analiz 1, Ankara: Global Politika ve Strateji Yayını.

Demirel, E. T. (2018). Araştırma Tasarımı, (içinde) Sosyal Bilimlerde Araştırma Yöntemleri, (ed.) Şebnem Arslan, Konya: Eğitim Yayınevi.

Deutsche Welle Türkçe (2020). Suriyelilere yardım tartışması: Tepkiler yerel yönetimlere yöneliyor, 17 Aralı 2020 tarihinde https://www.dw.com/tr/ suriyelilere-yard $\% \mathrm{C} 4 \% \mathrm{~B} 1 \mathrm{~m}$-tart $\% \mathrm{C} 4 \% \mathrm{~B} 1 \% \mathrm{C} 5 \% 9 \mathrm{Fmas} \% \mathrm{C} 4 \% \mathrm{~B} 1$-tepkiler-yerel$\mathrm{y} \% \mathrm{C} 3 \% \mathrm{~B} 6$ netimlere-y\%C3\%B6neliyor/a-48365681 adresinden erişildi.

Doğan, F. (2019). Yabancı ile bir arada yaşama ve ötekileştirme: Mardin halkının bakışından Suriyeli sı̆̆ıımacılar (Yüksek Lisans Tezi) Adnan Menderes Üniversitesi Sosyal Bilimler Enstitüsü.

Dukes, T., \& Musterd, S. (2012). Towards social cohesion: bridging national integration rhetoric and local practice: the case of the Netherlands. Urban Studies, 49 (9), 1981-1997.

Dülgergil, Ç. T., Demirel, G., Göçebe, B., \& Dalli, M. (2017). Kahramanmaraş İli Mülteci Kampındaki Suriyeli Çocuklarda Çürük Görülme Sıklığının Değerlendirilmesi. Türkiye Klinikleri. Diş Hekimliği Bilimleri Dergisi, 23 (1), 1-8.

Ekici, H. (2019). Türk Toplumunda Suriyelilere Yönelik Algllanan Tehditler Ve Çözüm Önerileri. Sosyal Politika Çalışmaları Dergisi, 19(44), 695-730.

Erdoğan, M. (2014). Türkiye'deki Suriyeliler: Toplumsal Kabul ve Uyum Araştırması. Hacettepe Üniversitesi Göç ve Siyaset Araştırmaları Merkezi, Ankara.

Erdoğan, M. M. (2020). Suriyeliler barometresi 2019: Suriyelilerle uyum içinde yaşamın çerçevesi. İstanbul: Orion Kitabevi.

Eşigül, A., Arslan, B. K., Gencer, A. Ş., Tosun, S., Korkmaz, S. S. \& Yıldırım, Ş. B. (2017). Bilgiden Algıya: Türkiye’deki Sığınmacı, Göçmen ve Mülteci Algısı Üzerine Bir Çalışma. Avrupa Siyasal ve Sosyal Araştırmalar Enstitüsü - PS:EUROPE.

Euronews (2019). Bolu’nun yeni CHP’li Belediye Başkanı Özcan'dan ilk icraat: Suriyeli mültecilere yardım kesildi. 18.12.2020 tarihinde https://tr.euronews.com/2019/04/10/ bolu-nun-yeni-chp-li-belediye-baskani-ozcan-dan-ilk-icraat-suriyeli-multecilereyardim-yok adresinden erişildi. 
Faist, T. (2012). Transnational migration. The Wiley-Blackwell Encyclopedia of Globalization.

Göç İdaresi Genel Müdürlüğü (GİGM) (2020). Y1llara Göre Geçici Koruma Kapsamındaki Suriyeliler, 07.01.2020 tarihinde https://www.goc.gov.tr/gecici-koruma5638 adresinden erişildi.

Gözübüyük Tamer, M. G. (2016). Trabzon Kamuoyunun Geçici Koruma Kapsamındaki Suriyelilere Bakış Açısı. Karadeniz Araştırmaları Enstitüsü Dergisi, 2 (2), 180-211.

Favell, A. (2001). Integration policy and integration research in Europe: a review and critique. (in) Citizenship today: global perspectives and practices, (Ed. T. Alexander Aleinikoff, Douglas Klusmeyer), Brookings Institution Press, 349, 351-352.

Gray, B. (2006). Migrant integration policy: A nationalist fantasy of management and control? Translocations: The Irish Migration, Race and Social Transformation Review 1(1), 118-138.

Göker, G. ve Keskin, S. (2015). Haber medyası ve mülteciler: Suriyeli Mültecilerin Türk yazılı basınındaki temsili. Iletişim Kuram ve Araştırma Dergisi, 41, 229-256.

Güney, Ü., \& Konak, N. (2016). Bolu'da Suriyeli ve Iraklı Sığınmacılar: Milliyetçilik, Erillik ve Vatandaşlık Temelinde Öteki Algısı. Alternatif Politika, 8(3), 505-535.

Haber46 (2020). Kahramanmaraş’ta şehit cenazesinde yüzlerce kişi Suriyelilere saldırdı, 20.12.2020 tarihinde https://www.haber46.com.tr/guncel/kahramanmaras-ta-sehitcenazesinde-yuzlerce-kisi-suriyelilere-h365088.html adresinden erişildi.

Harunoğulları, M., Hatunoğlu, Z., Polat, Y., \& Kılıç, M. (2018). Kahramanmaraş Esnafinın Sosyo Ekonomik Durumu ve Suriyeli Sığınmacılara İlişkin Görüşünün Belirlenmesi. Kahramanmaraş Sütçü İmam Üniversitesi İktisadi ve İdari Bilimler Fakültesi Dergisi, 8(1), 115-144.

Haşıloğlu, S. B., Baran, T., \& Aydın, O. (2015). Pazarlama araştırmalarındaki potansiyel problemlere yönelik bir araştırma: Kolayda örnekleme ve sıklık ifadeli ölçek maddeleri. Pamukkale Işletme ve Bilişim Yönetimi Dergisi, 2(1), 19-28.

Hickman, M. J., Mai, N., \& Crowley, H. (2012). Migration and Social Cohesion in the $U K$. Palgrave Macmillan.

Hürriyet (2014). Kahramanmaraş'ta 'Suriyelileri istemiyoruz' yürüyüşünde olaylar çıtı, 20.12.2020 tarihinde hurriyet.com.tr/gundem/kahramanmarasta-suriyelileriistemiyoruz-yuruyusunde-olaylar-cikti-26800668 adresinden erişildi.

İçduygu, A., Sirkeci, İ. \& Aydıngün, İ. (1998). Türkiye'de içgöç ve içgöçün işçi hareketine etkisi. (Ed. Ahmet İçduygu, İbrahim Sirkeci ve İsmail Aydıngün), Türkiye'de içgöç: Türkiye' de içgöç Sorunsal Alanları ve Araştırma Yöntemleri Konferansı Bolu-Gerede, 6-8 Haziran 1997 içinde (s. 207-249). İstanbul: Tarih Vakfı Yurt Yayınları.

İçduygu, A. \& Aksel, D. B. (2012). Türkiye'de Düzensiz Göç. Ankara: Uluslararası Göç Örgütü Türkiye. 
İstanbul Politik Araştırmalar Enstitüsü (2020). İstanbul〉da Suriyeli Sı̆̆ınmacılara Yönelik Tutumlar, 18.12.2020 tarihinde https://www.istanpol.org/post/i\%CC\%87stanbul-dasuriyeli-s $\% \mathrm{C} 4 \% \mathrm{~B} 1 \% \mathrm{C} 4 \% 9 \mathrm{~F} \% \mathrm{C} 4 \% \mathrm{~B} 1$ nmac\% $\% \mathrm{C} 4 \% \mathrm{~B} 1$ lara-y $\% \mathrm{C} 3 \% \mathrm{~B} 6$ nelik-tutumlar adresinden erişildi.

Jacob, A. G. (1994). Social integration of Salvadoran refugees. Social Work, 39 (3), $307-$ 312.

Kemik, P., Gözübüyük, M., \& Sever, M. (2019). Suriyeli Sığınmacıların Yoğun Yaşadığ1 Bölgelerdeki Yerel Halkın Suriyeli Sığınmacılara İlişkin Görüşleri: Altındağ Örneği. Mukaddime, 10 (2), 582-596.

Kırlığlu, M., \& Gencer, T. E. (2020). Göçmen ve Sığınmacılarla Sosyal Hizmet Dersinin Sosyal Hizmet Öğrencilerinin Suriyelilere Yönelik Algısına Etkisi. Toplum ve Sosyal Hizmet, 31 (3), 1127-1152.

Kurt, Ş. (2006). İşsizliğin Psiko-Sosyal Sonuçları ve Türkiye Üzerine Muhtemel Etkileri. Sosyal Siyaset Konferansları Dergisi, (51), 357-379.

Lee, E. S. (1966). A Theory of Migration, Migration. Demography, 3(1), 47-57.

Kahraman, F. ve Nizam, Ö. K. (2016). Mültecilik hallerini mekân üzerinden okumak: Gaziantep örneğinde Türkiyelilerin gözünden Suriyeli kent mültecileri. Uluslararası Sosyal Araştırmalar Dergisi, 9(44), 808-825.

Man, F. (2016). Günah Keçileri” ya da “Olağan Şüpheliler” Olarak Suriyeliler, Çalışma ve Toplum, 2016(3), 1147-1170.

Marmara Belediyeler Birliği (2015). Kent Mültecilerine Hizmette Belediyelerin Rolü Çalıştay Raporu,https://marmara.gov.tr/UserFiles/Attachments/2017/04/14/28b3e8d5e08a-4f5a-a310-b3c71b91b23d.pdf adresinden erişildi.

Marx, K. (2015). Kapital - Set 1-2-3, (Çev. Mehmet Selik, Erkin Özalp, Erkin Özalp), (Ed. Nail Satlıgan), İstanbul: Yordam Kitap.

Murray, K. E. ve Marx, D. M. (2013). Attitudes toward unauthorized immigrants, authorized immigrants, and refugees. Cultural Diversity and Ethnic Minority Psychology, 19(3), 332-341.

Orak, A. (2019). Suriyeli mültecilerin yerleşme sorunu ve çözüm arayışları: Kahramanmaraş örneği. (Yayınlanmamış Yüksek Lisans Tezi), İstanbul: Marmara Üniversitesi Orta Doğu ve İslam Ülkeleri Araştırmaları Enstitüsü.

Oytun, O. ve Gündoğar, S. S. (2015). Suriyeli Sığınmacıların Türkiye’ye Etkileri Raporu, ORSAM- TESEV Rapor No: 195, Ankara.

Özkaya, E., Kirişci, Ö., Çalışkan, A., Tümer, S., \& Şenol, H. (2015). Son İki Yılda Kahramanmaraş Necip Fazıl Şehir Hastanesine Başvuran Suriye Kökenli ve Suriye Kökenli Olmayan Hastalara Ait Serum Örneklerindeki HBsAg, Anti-HBs ve AntiHCV Pozitifliklerinin Değerlendirilmesi. FLORA, 20(3), 128-132.

Penninx, R., \& Garcés-Mascareñas, B. (2016). The concept of integration as an analytical tool and as a policy concept. (in) Integration processes and policies in Europe (pp. 11-29). Springer, Cham. 
Pezirkianidis, C., Stalikas, A., Efstathiou, E., \& Karakasidou, E. (2016). The relationship between meaning in life, emotions and psychological illness: The moderating role of the effects of the economic crisis. The European Journal of Counselling Psychology, $4(1), 1-24$.

Piore, M. J. (1979). Birds of Passage: Migrant Labor and Industrial Societies. Cambridge: Cambridge University Press.

Polat, F. ve Kaya, E. (2017). Bir ötekileştirme Pratiği: Türkiye'de yaşayan Suriyelilere yönelik tutumlar. Mersin Üniversitesi Sosyal Bilimler Enstitüsü e-Dergi, 1(1), 38-48.

Ravenstein, E. G. (1885). The Laws of Migration, Journal of the Statistical Society of London. 48 (2), 167-235.

Riek, B. M., Mania, E. W. ve Gaertner, S. L. (2006). Intergroup threat and outgroup attitudes: A meta-analytic review. Personality and Social Psychology Review, 10(4), 336-353.

Saçan, S., Cizdan, G., \& Tabak, H.D. (2017). Aydın Halkının Suriyeli Göçmenlere Yönelik Bakış Açısının İncelenmesi. Adnan Menderes Üniversitesi Sağlık Bilimleri Fakültesi Dergisi, 1(1), 28-38.

Sığınmacılar ve Göçmenlerle Dayanışma Derneği (SGDD). (2011). Askııaki yaşamlar \& algıdaki yaşamlar araştırma raporu. 22.12.2020 tarihinde http://sgdd.org.tr/wp-content/ uploads/2016/11/Askidaki_Yasamlar_Algidaki_Yasamlar.pdf adresinden erişildi.

Stark, O. (1991). The Migration of Labor. Cambridge: Basil Blackwell.

Stouffer, S. A. (1940). Intervening Opportunities: A Theory Relating Mobility and Distance. American Sociological Review, 5 (6), 845-867.

Sönmez, M. E. \& Adıgüzel, F. (2017). Türkiye'de Suriyeli sığınmacı algısı: Gaziantep şehri örneği. Gaziantep University Journal of Social Sciences, 16(3), 797-807.

Şimsek, A. (2012). Araştırma Modelleri, (içinde) Sosyal Bilimlerde Araştırma Yöntemleri, (Ed.) Ali Şimşek, Eskişehir: Anadolu Üniversitesi Yayınları.

Şen, G. \& Şimşek, H. (2019). Türkiye'deki kamu yönetimi öğrencilerinin Suriyeli sı̆̆ınmacılara ilişkin tutumları. Manas Sosyal Araştırmalar Dergisi, 8(2), 1958-1974.

Taştan, C., Haklı, S. Z., \& Osmanoğlu, E. (2017). Suriyeli sı̆̆ınmacılara dair tehdit algısı: Önyargılar ve gerçekler. Ankara: Polis Akademisi Başkanlığı Göç ve Sınır Güvenliği Araştırmaları Merkezi (GÖÇMER) Yayınları.

Topkaya, Y., Akdağ, H. (2016). Sosyal Bilgiler Öğretmen Adaylarının Suriyeli Sığınmacılar Hakkındaki Görüşleri (Kilis 7 Aralık Üniversitesi Örneği). Çankırı Karatekin Üniversitesi Sosyal Bilimler Enstitüsü Dergisi, 7(1), 767-786.

Türkiye İstatistik Kurumu (TUIK) (2020). Iş̧ücü İstatistikleri, Temmuz 2020, 10.12.2020 tarihinde www.tuik.gov.tr adresinden erişildi.

Türkiye Büyük Millet Meclisi (TBMM) (2019). Meclis Haber, 17.11.2020 tarihinde https:/www.tbmm.gov.tr/develop/owa/haber_portal.aciklama?p1=147662 adresinden erişildi. 
Valtonen, K. (1999). The Integration of Refugees in Finland in the 1990s (No. 224). Helsinki: Ministry of Labour.

Yazbek, S. (2012). Suriye Devrim Günlükleri: Çapraz Ateşte Bir Kadın, İstanbul: Timaş Yayınlar1.

Yiğit Özüdoğru, H., Kan, A., Uslu, L., \& Yaman, E. (2018). Yerel Halkın Suriyelilere Yönelik Tutum Ölçeği geliştirme çalışması. Sosyal Politika Çalışmaları Dergisi, 40(2), 115-140.

Yiğit Özüdoğru, H. \& Kan, A. (2020). Halkın Suriyelilere Yönelik Tutumunun İletişim ve İlişki Düzeyine Göre İncelenmesi. International Journal of Geography and Geography Education, (42), 244-262.

Yılmaz, L. Y. (2017). Yerel Halkın Türkiye'deki Suriyelilere Bakışı: Kilis, Gaziantep, Şanlıurfa, Hatay ve Adana Örnekleri (Yayınlanmamış Doktora Tezi), Ankara Yıldırım Beyazıt Üniversitesi Sosyal Bilimler Enstitüsü.

Woods, A. \& Kayal1, N. (2017). Suriyeli topluluklarla etkileşim: Istanbul da ki yerel yönetimlerin rolü. İstanbul Politikalar Merkezi. 
